\title{
The thin edge of the wedge: extremely high extinction risk in wedgefishes and giant guitarfishes
}

Peter M. Kyne ${ }^{1}$, Rima W. Jabado ${ }^{2}$, Cassandra L. Rigby ${ }^{3}$, Dharmadi ${ }^{4}$, Mauvis A. Gore ${ }^{5}$, Caroline M. Pollock ${ }^{6}$, Katelyn B. Herman ${ }^{7}$, Jessica Cheok ${ }^{8}$, David A. Ebert ${ }^{9,10}$, Colin A. Simpfendorfer ${ }^{3}$, Nicholas K. Dulvy ${ }^{8}$

1. Research Institute for the Environment \& Livelihoods, Charles Darwin University, Darwin, Northern Territory, Australia

2. Elasmo Project, Dubai, United Arab Emirates

3. Centre for Sustainable Tropical Fisheries and Aquaculture \& College of Science and Engineering, James Cook University, Queensland, Australia

4. Center for Fisheries Research, Ministry of Marine Affairs and Fisheries, Jakarta, Indonesia

5. Marine Conservation International, South Queensferry, United Kingdom

6. IUCN (International Union for Conservation of Nature) Global Species Programme - Red List Unit, Cambridge, United Kingdom

7. Georgia Aquarium, Atlanta, Georgia, USA

8. Earth to Ocean Research Group, Department of Biological Sciences, Simon Fraser University, Burnaby, British Colombia, Canada

9. Pacific Shark Research Center, Moss Landing Marine Laboratories, Moss Landing, California, USA

10. Research Associate, South African Institute for Aquatic Biodiversity, Grahamstown, South Africa 


\section{Abstract}

1. The process of understanding the rapid global decline of sawfishes (Pristidae) has revealed great concern for their relatives, the wedgefishes (Rhinidae) and giant guitarfishes (Glaucostegidae), not least because all three families are targeted for their high-value and internationally-traded 'white' fins.

2. The objective of this study was to assess the extinction risk of all 10 wedgefishes and 6 giant guitarfishes by applying the International Union for Conservation of Nature (IUCN) Red List Categories and Criteria, and to summarise their biogeography and habitat, life history, exploitation, use and trade, and population status.

3. Wedgefishes and giant guitarfishes have overtaken sawfishes as the most imperilled marine fish families globally, with all but one of the 16 species facing an extremely high risk of extinction due to a combination of traits - limited biological productivity, presence in shallow waters overlapping with some of the most intense and increasing coastal fisheries in the world, and over-exploitation in target and bycatch fisheries driven by the need for animal protein and food security in coastal communities and trade in meat and high-value fins.

4. Two species with very restricted ranges, the Clown Wedgefish (Rhynchobatus cooki) of the Indo-Malay Archipelago and the False Shark Ray (Rhynchorhina mauritaniensis) of Mauritania may be very close to extinction.

5. Only the Eyebrow Wedgefish (Rhynchobatus palpebratus) is not assessed as Critically Endangered, due to it occurring primarily in Australia where fishing pressure is low, and some management measures are in place. Australia represents a 'lifeboat' for the three wedgefish and one giant guitarfish species occurring there.

6. To conserve populations and permit recovery, a suite of measures will be required which will need to include species protection, spatial management, bycatch mitigation, and harvest and international trade management, all of which will be dependent on effective enforcement.

Key words: elasmobranchs, fisheries, IUCN Red List, shark-like rays, threatened species, wildlife trade 
bioRxiv preprint doi: https://doi.org/10.1101/595462; this version posted June 10,2019 . The copyright holder for this preprint (which was not certified by peer review) is the author/funder, who has granted bioRxiv a license to display the preprint in perpetuity. It is made available under aCC-BY-NC-ND 4.0 International license.

\section{INTRODUCTION}

One of the defining features of the Anthropocene will be the loss of biodiversity, both on land and in the oceans (Dirzo et al., 2014; McCauley et al., 2015). The oceans face a wide range of threats but our understanding of how these drive population decline and extinction in individual species remains poor. There has long been concern for the extent of marine declines but relatively few local, regional, and global extinctions have been documented (Dulvy, Sadovy, \& Reynolds, 2003; Dulvy, Pinnegar, \& Reynolds, 2009; McCauley et al., 2015). Nevertheless, the challenges of monitoring marine species, in particular those that do not surface to breathe or do not return to land to breed (such as marine mammals, reptiles, and seabirds), may mean that marine extinctions are underestimated, and indeed humanity may be on the cusp of witnessing a marine extinction pulse (McCauley et al., 2015). Systematically evaluating extinction risk in marine species is therefore critical to understand patterns of decline and to drive management and conservation measures in an attempt to limit extinction.

The chondrichthyan fishes - sharks, rays, and ghost sharks (i.e. chimaeras) (hereafter referred to as 'sharks and rays') are a marine group with elevated extinction risk; an estimated quarter of species are threatened globally (Dulvy et al., 2014). This extinction risk assessment reveals that sawfishes, wedgefishes, and guitarfishes are amongst the most threatened families and are of global conservation concern (Dulvy et al., 2016; Jabado, 2018; Moore, 2017). Recent advances in taxonomy and phylogenetics have resolved some of the complex relationships of these rays (Faria et al., 2013; Last, Séret, \& Naylor, 2016b; Last et al., 2016c) enabling a new assessment of their status. The order Rhinopristiformes was resurrected by Last et al. (2016b) and is now considered to consist of the sawfishes (family Pristidae), wedgefishes (Rhinidae), giant guitarfishes (Glaucostegidae), guitarfishes (Rhinobatidae), and banyo rays (Trygonorrhinidae). Collectively, these groups can be referred to as the 'shark-like rays' given their phylogenetic position as rays, but morphological similarities to sharks (in particular the shark-like posterior body, including dorsal and caudal fins).

An accurate assessment of extinction risk requires the delineation of taxonomic units. The sawfishes have historically been plagued by poor taxonomic resolution and species delineation (Faria et al., 2013), and similarly, the status of wedgefishes has been challenging to understand because of uncertain species identification (Jabado, 2019). The 'whitespotted wedgefish' (i.e. Rhynchobatus djiddensis) species-complex has been poorly-defined with the name 'Rhynchobatus djiddensis' used widely for wedgefishes across the Indo-West Pacific Ocean region prior to clarification of species distributions and recognition that $R$. djiddensis is in fact restricted to the Western Indian Ocean (Last et al., 2016c). Additionally, several new wedgefish species have been recently described (Last, Ho, \& Chen, 2013; Last, Kyne, \& Compagno, 2016a; Séret \& Naylor, 2016), and while species identification 
remains an issue in the field, species taxonomic boundaries and geographical distributions are now well enough defined to allow a more accurate assessment of global extinction risk.

The international trade in shark fin for the Asian soup market has incentivised targeting and retention of sharks and shark-like rays (Dent \& Clarke, 2015). Sawfishes, wedgefishes, and giant guitarfishes all have 'white' fins, amongst the best quality and highest value in the fin trade (Dent \& Clarke, 2015; Hau, Abercrombie, Ho, \& Shea, 2018; Moore, 2017; Suzuki, 2002). Domestically, the meat is also an important protein source, linking the status of these species to livelihoods in developing tropical countries (Jabado, 2018; Moore, 2017; Moore, Séret, \& Armstrong, 2019). Sawfishes, wedgefishes, and guitarfishes were previously common in soft-bottom habitats of shallow, warm waters, but have been heavily exploited from exposure to intensive trawl and gillnet fisheries in these habitats (Jabado, 2018; Moore, 2017).

Conservation and management measures have lagged resource exploitation in the shark-like rays. Considerable progress has recently been made in raising awareness and implementing management for sawfishes following the release of a global conservation strategy (Fordham, Jabado, Kyne, Charvet, \& Dulvy, 2018; Harrison \& Dulvy, 2014), and urgency has been declared for action on wedgefishes and giant guitarfishes (Moore, 2017). High levels of exploitation and the increasing pattern of targeting for the international trade has led to concern that wedgefishes and giant guitarfishes are at extinction risk levels similar to sawfishes (Hau et al., 2018; Jabado, 2018; Moore, 2017). Extinction risk assessments for sawfishes were reviewed in 2013; these highlighted rapid declines, local extinctions, and the need for serious investment in conservation and management (see Dulvy et al., 2016; Harrison \& Dulvy, 2014). Extinction risk was previously assessed for most wedgefishes and giant guitarfishes between 2003 and 2007.

A global reassessment of extinction risk of all sharks and rays is being undertaken through the International Union for the Conservation of Nature (IUCN) Species Survival Commission Shark Specialist Group's Global Shark Trends Project. Wedgefishes and giant guitarfishes were prioritised for reassessment given the issues outlined above. Here, the IUCN Red List Categories and Criteria are applied to wedgefishes and giant guitarfishes globally. First, pertinent background information (biogeography and habitat; life history; and, exploitation, use, and trade) is reviewed before summarizing population trends and IUCN Red List categories.

\section{METHODS}

\section{$2.1 \quad$ Taxonomic scope}


The taxonomic scope of this study are the 10 recognised species of wedgefishes (Rhinidae) and six giant guitarfishes (Glaucostegidae) of the order Rhinopristiformes following Last et al. (2016c) (Tables $1 \& 2)$.

\subsection{Application of the IUCN Red List Categories and Criteria}

The IUCN Red List Categories and Criteria (Version 3.1) were applied following the Guidelines for Using the IUCN Red List Categories and Criteria (IUCN, 2012; IUCN Standards and Petitions Subcommittee, 2017). Assessments were undertaken at the global level, i.e. for the entire global population of each species. For each species, data on taxonomy, distribution, population status, habitat and ecology, major threats, use and trade, and conservation measures were collated from the peer-reviewed literature, fisheries statistics, grey literature, and consultation with species and fisheries experts.

Draft assessments were prepared in the IUCN Species Information Service (SIS) online database. Each assessment was peer-reviewed by at least two reviewers who were trained in the application of the IUCN Red List Categories and Criteria and who were familiar with shark-like rays and the fisheries interacting with them. A summary of the assessments was also provided to the entire IUCN Species Survival Commission Shark Specialist Group (SSG) for their consultation and input (174 members). Assessments were then submitted to the IUCN Red List Unit (Cambridge, UK) where they underwent further review and quality checks before being accepted for publication on the IUCN Red List (version 2019-2, July 2019, www.iucnredlist.org; IUCN, 2019).

The IUCN Red List applies eight extinction risk categories: Extinct (EX), Extinct in the Wild (EW), Critically Endangered (CR), Endangered (EN), Vulnerable (VU), Near Threatened (NT), Least Concern (LC), and Data Deficient (DD) (IUCN, 2012; Mace et al., 2008). A species is considered EX 'when there is no reasonable doubt that the last individual has died'; EW 'when it is known only to survive in cultivation, in captivity or as a naturalised population (or populations) well outside the past range'; $\mathrm{CR}$, EN, and $\mathrm{VU}$ species are considered to be facing an extremely high, very high, or high risk of extinction in the wild, respectively; NT species do 'not qualify for CR, EN or VU now, but is close to qualifying for or is likely to qualify for a threatened category in the near future'; LC species do not qualify for CR, EN, VU, or NT; finally, DD species have 'inadequate information to make a direct, or indirect, assessment of its risk of extinction based on its distribution and/or population status (IUCN, 2012).

Each species was assessed against the five Red List criteria: A - population size reduction; B geographic range size; C - small population size and decline; D - very small or restricted population; and, E - quantitative analysis (for example, population viability analysis) (see IUCN, 2012; IUCN 
Standards and Petitions Subcommittee, 2017; Mace et al., 2008). To qualify for one of the three threatened categories (CR, EN, or VU), a species has to meet a quantitative threshold for that category in any of the five criteria listed above (A-E). A collation and review of available information indicated that there were no data available to assess species under criteria $C, D$, or E, and these criteria are therefore not considered further here. All species were assessed under criterion A, with some consideration of criterion $\mathrm{B}$ for range restricted species.

Criterion A applies a set of quantitative thresholds to consider population reduction scaled over a period of three generation lengths (3 GL) (IUCN Standards and Petitions Subcommittee, 2017; Mace et al., 2008). While there are a range of demographic approaches to calculating generation length (IUCN Standards and Petitions Subcommittee, 2017), these are generally data intensive and have not been applied to any wedgefish or giant guitarfish. Therefore, to derive generation length (GL), a simple measure that requires only female age-at-maturity and maximum age was used:

$\mathrm{GL}=(($ maximum age - age-at-maturity $) / 2))+$ age-at-maturity

This value represents the median age of parents of the current cohort. To derive population reduction over $3 \mathrm{GL}$, the proportional decline over the $x$ years of available catch rate or landings datasets was calculated and this was used to calculate annual proportional change, which was then scaled across the $3 \mathrm{GL}$ period.

\subsection{Distribution mapping}

A global distribution map (Appendix I) was generated for each species, primarily following the ranges in Last et al. (2016c), with some minor modifications based on new records. Ranges were clipped to the maximum depth of each species, and for those wedgefishes without known depth ranges, these were set to the maximum confirmed depth of the family $(70 \mathrm{~m}$; Table 1$)$. To determine global patterns of biodiversity, species richness maps were produced for all species combined, wedgefishes only, and giant guitarfishes only. All maps were prepared using ArcMap 10.4 (ESRI, 2016).

\subsection{Calculation of a Red List Index}

A Red List Index (RLI) was calculated based on the number of species in each Red List category at each of three time periods. The index was calculated as the weighted sum of species status scaled by the number of species. An 'equal-step' weighting was used where the weight $\left(W_{c}\right)$ equals zero for LC, 1 NT, 2 - VU, 3 - EN, 4 - CR, and 5 - EX or EW. Hence, a species moving from LC to NT will contribute as much to the index as a species moving from EN to CR. The RLI is scaled to range from 1 (where all 
157

where $M$ is the maximum threat score, which is the number species multiplied by the maximum weight assigned to EX species (here, a value of 5), and in this case for 16 species is $16 \times 5=80$. The current threat score $\left(T_{t}\right)$ is the sum of the number of species in each threat category in year $t\left(N_{c(t)}\right)$, times the category weight $\left(W_{c}\right)$.

$T_{t}=\sum_{c} N_{c(t)} W_{c}$

Hence, the threat score for the current assessment would be calculated as the $N_{c(t)}=15$ species that are Critically Endangered $\left(W_{c}=4\right)$, giving $4 \times 15=60$, summed with the one Near Threatened species $\left(W_{c}=1\right)$. Thus, the current threat score $T_{t=2019}$ is $60+1=61$ and the $R L I_{t=2019}=(80-61) / 80=0.2375$.

Retrospective assessments were developed for two earlier time periods, which were chosen as 2005 and 1980 (with the current assessments set at 2020). Prior to this current reassessment, all six giant guitarfishes and seven of the wedgefishes had assessments published on the IUCN Red List (wedgefishes: 1 EN, 6 VU; giant guitarfishes: 1 EN, 5 VU). All changes in Red List category were considered to be non-genuine changes as a result of new information (IUCN Standards and Petitions Subcommittee, 2017). In other words, if what is currently understood was known during the previous assessments, it is likely that the assigned status of those species would have been different. 'Back casting' is undertaken by retrospectively assigning status based on current understanding of the spatial and temporal pattern of coastal human population growth, the development of general fishing pressure, an understanding of the availability of fishing gear capable of capturing sharks and rays, and the development of the international trade demand for shark and shark-like ray fins (e.g. Blaber et al., 2019; Clarke, Milner-Gulland, \& Bjorndal, 2007; Cripps, Harris, Humber, Harding, \& Thomas, 2015; Sousa, Marshall, \& Smale, 1997; Stewart et al., 2010).

Red List Indices were also calculated for the two main oceanic regions, the Indo-West Pacific Ocean region (hereafter, 'Indo-West Pacific'), and the Eastern Atlantic Ocean and Mediterranean Sea region (hereafter, 'Eastern Atlantic'), as well as individually for each of the 87 countries containing some proportion of at least one of the 16 species assessed here. Threat scores applied to the two oceanic regions followed the equal-step weighting outlined above. For disaggregating the global RLI to the national level, the equation is amended such that:

$R L I_{(t, u)}=1-\left[\frac{\sum\left(W_{(t, s)} \times \frac{r_{s u}}{R_{S}}\right)}{W E X \times \sum\left(\frac{r_{S u}}{R_{S}}\right)}\right]$ 
where $t$ is the year of assessment, $u$ is the country and $W_{(t, s)}$ is the Red List threat at year $t$ for each species, multiplied by $\frac{r_{s u}}{R_{s}}$, which represents the proportion of each species' total range found within the Exclusive Economic Zone (EEZ) of each country. This is summed across all species found in each country's EEZ and divided by the maximum threat score $(W E X=5)$, multiplied by the sum of proportional species' ranges. The final RLI value is derived from subtracting by 1 so that higher RLI values indicate less negative changes in Red List status across species and vice versa (as with the global RLI). Finally, the national conservation responsibility for all species were calculated separately for each of the two oceanic regions, based on the sum of all threat scores across species within a country multiplied by each of the species' proportional ranges for that country. Resulting national responsibility values were normalized to range between 0 and 1 for both regions.

\section{RESULTS}

Here, summaries of (1) biogeography and habitat; (2) life history; (3) exploitation, use and trade; (4) population status; (5) IUCN Red List Categories; (6) the possible extinction of two wedgefish species; and, (7) the Red List Index for wedgefishes and giant guitarfishes, are presented.

\subsection{Biogeography and habitat}

The Indo-West Pacific is the centre of diversity for wedgefishes (8 species) and giant guitarfishes (5 species), with the remaining three species occurring in the Eastern Atlantic (including the Mediterranean Sea for the Blackchin Guitarfish (Glaucostegus cemiculus)) (Tables 1 \& 2, Figure 1, Appendix I). Distributions range from extremely widespread, i.e. Bowmouth Guitarfish (Rhina ancylostoma) and Bottlenose Wedgefish (Rhynchobatus australiae) to the very restricted, i.e. Taiwanese Wedgefish (Rhynchobatus immaculatus), Clown Wedgefish (Rhynchobatus cooki), and False Shark Ray (Rhynchorhina mauritaniensis) (Appendix I). These latter three species are known only from fish landing sites in northern Taiwan, Singapore and Jakarta, and Mauritania, respectively (Last et al., 2013; 2016a; Séret \& Naylor, 2016), and therefore their exact distributions remain undefined. Rhynchorhina mauritaniensis is potentially the most range-restricted species, as it is currently only known from a single location, the Banc d'Arguin National Park in Mauritania (Séret \& Naylor, 2016).

Both families primarily occur in tropical to warm temperate waters from close inshore to the mid continental shelf, although two species (R. ancylostoma, $R$. australiae) are also known to occur around island chains far from continental landmasses; wedgefishes occur to a maximum depth of at least 70 $\mathrm{m}$ (although exact depth ranges are unknown for three species) and giant guitarfishes to a maximum of $120 \mathrm{~m}$ (Tables 1 \& 2; Last et al., 2016c). Some species have been recorded from the estuarine reaches of rivers and the Broadnose Wedgefish (Rhynchobatus springeri) is thought to be a habitat 
217

218

219

220

221

222

223

224

225

226

227

228

229

230

231

232

233

234

235

236

237

238

239

240

241

242

243

244

245

246

247

specialist of shallow brackish coastal and estuarine waters (Compagno \& Last, 2010), while others can be associated with coral reefs (e.g. R. ancylostoma).

\subsection{Life history}

The life history of wedgefishes and giant guitarfishes is generally very poorly known, with only a limited number of dedicated studies on aspects of their biology and ecology, with the exception of $G$. cemiculus. Wedgefishes are large species, with most species reaching $>200 \mathrm{~cm}$ total length (TL) and up to $310 \mathrm{~cm}$ TL in the Whitespotted Wedgefish (Rhynchobatus djiddensis), although R. cooki is an exceptionally small species ( $81 \mathrm{~cm} \mathrm{TL}$ ), while maximum size is unknown for $R$. immaculatus (the largest collected specimen was still immature at $99 \mathrm{~cm}$ TL) (Table 1). Giant guitarfishes reach $300 \mathrm{~cm}$ TL (Clubnose Guitarfish, Glaucostegus thouin) with most species $>200 \mathrm{~cm} \mathrm{TL}$, except the Halavi Guitarfish (Glaucostegus halavi; $187 \mathrm{~cm} \mathrm{TL)}$ and the Widenose Guitarfish (Glaucostegus obtusus; $93 \mathrm{~cm} \mathrm{TL).} \mathrm{Size-}$ at-maturity and size-at-birth are poorly-known with data gaps for most species (Tables $1 \& 2$ ).

Reproduction is lecithotrophic viviparous in both families with generally small, but variable litter sizes: in the wedgefishes, from as low as 2 pups per litter in R. ancylostoma (range: 2-11) and the African Wedgefish (Rhynchobatus luebberti) (2-5), to as high as 19 pups per litter in R. australiae (7-19), and in the giant guitarfishes, from a low of 4 pups per litter in G. obtusus (4-10) to as high as 24 pups per litter in G. cemiculus (Tables 1 \& 2). Glaucostegus cemiculus exhibits some regional variation with 1624 pups per litter in Senegal and 5-12 in Tunisia. Litter sizes are available for only 4 of 10 wedgefishes and 4 of 6 giant guitarfishes. Reproductive periodicity is suspected to be annual in G. cemiculus (Capapé \& Zaouali, 1994), but periodicity, and therefore annual fecundity, are largely unknown across the two families.

There is a general lack of age and growth data. For wedgefishes, the only study (White, Simpfendorfer, Tobin, \& Heupel, 2014) was based on mixed samples of $R$. australiae and the Eyebrow Wedgefish (Rhynchobatus palpebratus), and therefore has limited biological meaning. Maximum observed age was 12 years (female of $183 \mathrm{~cm} \mathrm{TL}$ ) (White et al., 2014) which would be well below longevity given that $R$. palpebratus reaches $262 \mathrm{~cm}$ TL and $R$. australiae reaches $\sim 300 \mathrm{~cm}$ TL. For giant guitarfishes, a maximum observed age for the Giant Guitarfish (Glaucostegus typus) of 19 years ( $250 \mathrm{~cm}$ TL female) was reported by White et al. (2014) and while age-at-maturity was not reported, it can be estimated from the growth curve as 7 years (by reading the corresponding age at $165 \mathrm{~cm} \mathrm{TL}$, the mid-point of size-at-maturity; Last et al., 2016c). This estimate is not sex-specific as the growth curve of White et al. (2014) was based on combined sexes. For G. cemiculus, a maximum observed age of 15 years (198 
$\mathrm{cm}$ TL female), a male of age-at-maturity of 2.9 years, and a female age-at-maturity of 5.1 years was reported by Enajjar, Bradai, \& Bouain (2012).

An estimate of generation length (GL) for G. cemiculus of 9.5 years based on the age data of Enajjar et al. (2012) is likely an underestimate given maximum observed age was for an individual well below maximum size (198 vs $265 \mathrm{~cm}$ TL). This GL estimate does, however give a suitable estimate for smaller ( $<200 \mathrm{~cm} \mathrm{TL}$ ) wedgefish and giant guitarfish species. A GL estimate for $G$. typus of 13 years based on the age data of White et al. (2014) is a reasonable estimate given that maximum observed age was for an individual close to maximum size (250 vs. $270 \mathrm{~cm} \mathrm{TL}$ ) (White et al., 2014). To ensure consistency across IUCN Red List Assessments, 15 years was applied as an estimated GL to large ( $\geq 200 \mathrm{~cm}$ TL) species, and 10 years for smaller species $(<200 \mathrm{~cm} \mathrm{TL})$.

\subsection{Exploitation, use, and trade}

Globally, wedgefishes and giant guitarfishes are subject to intense fishing pressure on their coastal and shelf habitats (Stewart et al., 2010) that is unregulated across the majority of their distributions. They are captured in industrial, artisanal, and subsistence fisheries with multiple fishing gears, including gillnet, trawl, hook and line, trap, and seine net and are generally retained for their meat and fins (Bonfil \& Abdallah, 2004; Jabado, 2018; Moore, 2017). There is a high level of fisheries resource use and increasing fishing pressure which has resulted in the over-exploitation or depletion of demersal coastal fisheries resources in significant areas of the Indo-West Pacific and the Eastern Atlantic, including West Africa, India, and Southeast Asia (FAO, 2018b; Mohamed \& Veena, 2016; Pauly \& Chuenpagdee, 2003; Stewart et al., 2010; Stobutzki et al., 2006). The major exception is Australia where fishing pressure is considerably lower (this is also the case for some smaller range states such as New Caledonia, and South Africa which are at the geographic limit of the range of a small number of species).

In general, fishing effort and the number of fishers has increased in recent decades across the range of these species, with demand for shark and ray products increasing over the same period due to the shark fin trade (Chen, 1996; Diop \& Dossa, 2011; Jabado et al., 2017). Several examples of this increase from across the global range of wedgefishes and giant guitarfishes include (1) Mauritania which has seen a significant increase in fishing effort since the second half of the 20th Century: in 1950 there were 125 pirogues (small-scale fishing boats), rising to nearly 4,000 in 2005 (Belhabib et al., 2012); (2) Senegal, where the number of artisanal pirogues rose from 5,000 in 1982 to 12,699 in 2006, although it has since fallen slightly to 11,889 in 2013 (ANSD, 2016; FAO, 2008); (3) Madagascar, where the number of pirogues rose from 5,000 in 1983 to 22,000 in 1996 (Cooke, 1997); (4) the Red Sea, where 
the number of traditional boats tripled from 3,100 to 10,000 from 1988 to 2006 (Bruckner, Alnazry, \& Faisal, 2011); and, (5) the Indian state of Gujarat, where the number of trawlers increased from about 6,600 in the early 2000s to 11,582 in 2010 (CMFRI, 2010; Jabado et al., 2017; Zynudheen, Ninan, Sen, \& Badonia, 2004). This increasing fishing effort has put significant pressure on all species. Furthermore, the high value of fins is driving retention and trade of wedgefishes and giant guitarfishes globally, with these species targeted in the Mediterranean Sea, West Africa, East Africa, India, and the Indo-Malay Archipelago, among other places (Barrowclift, Temple, Stead, Jiddawi, \& Berggren, 2017; Diop \& Dossa, 2011; IOTC, 2005; Jabado, 2018; Lteif, 2015; Moore, 2017; Newell, 2016; Seisay, 2005).

Both the meat and fins drive utilisation and trade. The high-quality meat is consumed by many coastal communities in tropical countries and it is also dried, salted, and consumed locally or traded internationally (e.g. Moore, 2017; Jabado, 2018). Large whole wedgefishes (>200 cm total length; TL) have been traded for a high value of up to US\$680 each (e.g. Jabado, 2018). Prices for the highlyvalued 'white' fins of large shark-like rays are reportedly as high as US\$964/kg (Jabado, 2019). Other reported prices include US\$396/kg for wedgefish fins (Chen, 1996) and an average price of US\$276/kg and US\$185/kg for Qun chi (fins from shark-like rays) in Guangzhou (mainland China) and Hong Kong, respectively (Hau et al., 2018). In addition to meat and fins, other uses include the skin which may be dried and traded internationally as a luxury leather product (Haque, Biswas, \& Latifa, 2018), the eggs which are sometimes dried and consumed locally, the heads which may be dried and used as either fish meal or fertilizer (Haque et al., 2018; R.W. Jabado, unpubl. data), and the snout of giant guitarfishes are considered a delicacy in Singapore where they are steamed, and the gelatinous filling consumed.

\subsection{Population status}

\subsubsection{Data availability}

Where rhinopristoid rays have been targeted or exploited as incidental catch, severe declines, population depletions, and localised disappearances have occurred (e.g. Dulvy et al., 2016; Jabado, 2018; Moore, 2017; Tous, Ducrocq, Bucal, \& Feron, 1998). However, there are no species-specific time-series data available that can be used to calculate population reduction in wedgefishes and giant guitarfishes. Despite this, there are a number of relevant historical accounts and contemporary datasets for landings and catch rates. All of these accounts and datasets are from the Indo-West Pacific (from Iran to Indonesia), but can also be considered informative for understanding population reduction in wedgefishes and giant guitarfishes more broadly where they are under heavy exploitation, including in the Eastern Atlantic. The five contemporary datasets are available for 
landings data or catch rates at varying levels of taxonomic resolution (e.g. 'guitarfishes', 'whitespotted wedgefishes' etc.) from Iran, Pakistan, western and eastern India, and Indonesia. These datasets likely include various species of wedgefishes and giant guitarfishes and in each case, probable species are listed below. One dataset (Raje \& Zacharia, 2009) does not include rhinopristoids but rather presents landings data for myliobatoid rays (stingrays, eagle rays, butterfly rays, and devil rays). However, this can be used to infer declines in wedgefishes and giant guitarfishes given overlapping distributions, habitat, and susceptibility to capture in the same fishing gear. A summary of these datasets and corresponding proportional decline over $3 \mathrm{GL}$ is provided in Table 3.

\subsubsection{Indo-West Pacific}

\subsubsection{Historical accounts}

Research trawl survey data from the Gulf of Thailand showed a $93 \%$ decline in catch rates of 'Rhinobathidae' (a name that is likely to include wedgefishes and guitarfishes broadly) over a short time period from peak catches in 1968 to a low in 1972 (Pauly, 1979, Ritragsa, 1976). Similarly, catch rates of 'rays' declined by 92\% from 1963 to 1972. Secondly, the Indonesian Aru Islands wedgefish gillnet fishery rapidly expanded from its beginnings in the mid-1970s to reach its peak in 1987 with more than 500 boats operating before catches then declined very rapidly leading to only 100 boats left fishing in this area in 1996 (Chen, 1996). In all likelihood, the fleet redistributed to other areas as wedgefishes were depleted and catch rates declined. Thirdly, investors in Indonesia withdrew from a wedgefish fishery in the Malaku and Arafura Seas because the resource had been overfished by 1992 resulting in limited returns for their investment (Suzuki, 2002). Lastly, research trawl surveys in the Java Sea showed the decline of 'rays' between 1976 and 1997 by 'at least an order of magnitude' (i.e., a decline of at least 90\%) (Blaber et al., 2009). It is worth noting that recent trawl surveys in the Java Sea recorded only a single individual Rhynchobatus (Tirtadanu, Suprapto, \& Suwarso, 2018), and in the North Natuna Sea (north of the Java Sea), trawl surveys recorded only two individuals (Yusup, Priatna, \& Wagiyo, 2018).

\subsubsection{Iran landings dataset}

Landings data for the 'giant guitarfish' category are available from Iran for 1997-2016 (20 years; FAO, 2018a; Table 3). This grouping likely includes all rhinids (wedgefishes) and glaucostegids (giant guitarfishes) occurring locally, including $R$. ancylostoma, $R$. australiae, $R$. djiddensis, Smoothnose Wedgefish (Rhynchobatus laevis), Sharpnose Guitarfish (Glaucostegus granulatus), and G. halavi. Landings declined by $67 \%$ over this period, the equivalent of an $81 \%$ and $91 \%$ population reduction over the last $3 \mathrm{GL}$ of smaller species (30 years) and larger species (45 years), respectively. 


\subsubsection{Pakistan landings dataset}

345 Landings data for the 'rhinobatid' category are available from Pakistan for 1993-2011 (19 years)

346 covering the country's two coastal provinces (data collated from Pakistan Government records; M.A.

347 Gore, unpubl. data; Table 3). This grouping likely includes all rhinids and glaucostegids occurring 348 locally, including $R$. ancylostoma, R. australiae, R. laevis, G. granulatus, G. halavi, and G. obtusus, as 349 well as rhinobatids (guitarfishes) including Bengal Guitarfish (Rhinobatos annandalei). Data from Sindh 350 province showed a 72\% decrease from peak landings in 1999 to a low in 2011, the equivalent of a 95\% 351 and $99 \%$ population reduction over the last $3 \mathrm{GL}$ of smaller species (30 years) and larger species (45 352 years), respectively. Data from Balochistan province showed an $81 \%$ decrease from peak landings in 3531994 to the last data point in 2011, the equivalent of a $94 \%$ and $98 \%$ population reduction over the 354 last $3 \mathrm{GL}$ of smaller species (30 years) and larger species (45 years), respectively. No wedgefish or giant guitarfish were observed during surveys of southwest Balochistan fish landings between 2007 and 2010 (M.A. Gore and U. Waqas, unpubl. data).

\subsubsection{Western India ray catch rate dataset}

Catch rate data for myliobatoid rays (this includes a variety of demersal rays, but does not include rhinopristoids) are available from Maharashtra, western India for 1990-2004 (15 years; Raje and Zacharia, 2009; Table 3). The catch rate declined by $63 \%$ over this period (despite fishing effort doubling during this time), the equivalent of an $86 \%$ and $95 \%$ population reduction over the last $3 \mathrm{GL}$ of smaller species (30 years) and larger species (45 years), respectively.

\subsubsection{Eastern India landings dataset}

Landings data for 'guitarfishes' are available from Tamil Nadu, eastern India for 2002-2006 (5 years; Mohanraj, Rajapackiam, Mohan, Batcha, \& Gomathy, 2009). This grouping was reported in the paper to include $R$. ancylostoma, ' $R$. djiddensis' (which would therefore include $R$. australiae and $R$. laevis, since $R$. djiddensis does not occur in this area), G. granulatus, and G. obtusus, but was also likely to include $G$. thouin and G. typus. Landings declined by $86 \%$ over this period. Furthermore, speciesspecific trawl landings data were reported for 'R. djiddensis' (i.e. $R$. australiae and $R$. laevis), with a decline of $87 \%$ over this period. This time-period is however too short to derive an equivalent population reduction over three generations. 
Landings data for 'whitespotted wedgefishes' are available from Indonesia for 2005-2015 (11 years; DGCF, 2015; 2017; Table 3). This grouping likely includes $R$. ancylostoma, $R$. australiae, $R$. cooki, $R$. palpebratus, and $R$. springeri. It may also include giant guitarfishes, but in any case, the trends can be considered representative of giant guitarfishes occurring locally due to overlapping habitat and catchability (i.e. G. obtusus, G. thouin, and G. typus). Landings declined by $88 \%$ over this period, the equivalent of $>99 \%$ population reduction over the last $3 \mathrm{GL}$ of both smaller species (30 years) and larger species (45 years). An additional data point available for 2016 is excluded from this analysis. This datum suggests a massive increase in reported landings which is an artefact of the inclusion of a wider range of rays in the reported figure (DGCF, 2017; Muhammad Anas, pers. comm., 11/2/2019).

\subsubsection{East Africa anecdotal reports}

The above information spans Iran to Southeast Asia, with less information available from East Africa in the Western Indian Ocean. Anecdotal reports from this region suggest that artisanal longline fishing led to declines in R. djiddensis in southern Mozambique (which was one of the main target species of the fishery) as this species was abundant on reefs before longline fisheries began in the early 2000s and subsequently, are only seen in low numbers (Pierce et al., 2008). In Zanzibar, fisher interviews indicated that there were perceived declines in wedgefish or that they are rare (Schaeffer, 2004); wedgefishes were a retained bycatch of commercial prawn trawling in Tanzania (Rose, 1996). Intense fishing pressure across the Tanzanian shelf has likely resulted in population reduction, mirroring those outlined above for the Indo-West Pacific more broadly. In Madagascar, there was a decrease in the size of wedgefish caught in artisanal fisheries over time (Humber et al., 2017), though this could be due, in part, to the targeting of larger individuals. A steep decline in catch-per-unit-effort (CPUE) can be inferred from reported catch reductions from 10-20 sharks per day in 1992 to 1-3 sharks per day in 1995 in Morondava, West Madagascar, with fishers subsequently moving further afield to fish (Cooke, 1997). Wedgefish, a high-value target species, would likely have declined by a similar order of magnitude as sharks. In South Africa, there was a marked decline in CPUE of $R$. djiddensis in shark bather protection nets in KwaZulu-Natal during the period 1979-2017 (Nomfundo Nakabi, pers. comm., 17/04/2018). This decline is not considered to be a good indicator of population reduction as it may be explained, at least partially, by a shift in gear deployment whereby nets were gradually lifted off the substrate (which would reduce the capture of demersal species).

\subsubsection{Australia}

The one region in which wedgefish and giant guitarfish populations may be in a better state than most of the rest of their range is Australia. Here, fishing effort is relatively low, the use of turtle exclusion 
405

406

407

408

409

410

411

412

413

414

415

416

417

418

419

420

421

422

423

424

425

426

427

428

429

430

431

432

433

434

435

436

437

devices in trawl fisheries reduces the catch of large rays (Brewer et al. (2006) recorded a reduction of 94\%), and there are some controls on wedgefish catch and retention. Estimates of fishing mortality rates for wedgefish and giant guitarfish species in the Northern Prawn Fishery (the largest Australian fishery to interact these species) are well below those that would lead to significant population declines (Zhou \& Griffiths, 2008).

\subsubsection{Eastern Atlantic and Mediterranean Sea}

Data on population status in the Eastern Atlantic Ocean and Mediterranean Sea is sparse, but there are several lines of evidence to support similar population reductions, as well as local extinctions. In the Mediterranean Sea, G. cemiculus was regarded as historically common within both northern (de Buen, 1935; Doderlein, 1884) and southern (Bradaï, Saidi, Enajjar, \& Bouain, 2006; Quignard \& Capapé, 1971; Whitehead, Bauchot, Hureau, Nielsen, \& Tortonese, 1984) areas. However, there are now contrasting situations between these two areas. The species has largely disappeared from the northern Mediterranean Sea and was not recorded in extensive trawl surveys under the Mediterranean International Trawl Surveys (MEDITS) program from 1994 to 2015 (Newell, 2016; Relini \& Piccinetti, 1991), nor in trawl surveys in the Adriatic Sea between 1948 and 2005 (Ferretti, Osio, Jenkins, Rosenberg, \& Lotze, 2013). In the southern Mediterranean Sea (including the Gulf of Gabés and areas of the eastern Mediterranean, which seem to be core parts of the species' distribution), the species is still present and, in some areas, still commonly caught (e.g. Echwikhi, Saidi, \& Bradaï, 2014; Lteif, 2015; Newell, 2016; Soldo, Briand, \& Rassoulzadegan, 2014).

In West Africa, trend data are lacking, but evidence points to severe declines of wedgefishes. Rhynchobatus luebberti is known to have disappeared from a significant part of West Africa (Mauritania to Sierra Leone but apparently with the exception of the Banc d'Arguin National Park; Diop \& Dossa, 2011). However, the species is now sparsely reported in the Banc d'Arguin National Park with only two individuals recorded in the past decade during fish landing site monitoring (the most recent record being February 2019) (Sall Amadou, pers. comm., 14/02/19; Saïkou Oumar Kidé, pers. comm., 14/02/19). This species was moderately abundant across its former range in the 1960s but declined thereafter (Bernard Séret, pers. comm., 07/02/19); during Guinean trawl surveys in the $1960 \mathrm{~s}$, catch rates were as high as 30-34 kg/hr (William, 1968). By contrast, recent fish market surveys across the region have either failed to locate it or found only low numbers of individuals. In The Gambia, annual surveys from 2010 to 2018 of landing sites that regularly land guitarfishes and other rays have not recorded the species (Moore et al., 2019). In one artisanal demersal gillnet fishery in Mayumba, Gabon (between 30 to 40 boats), surveys between February 2013 and October 2015 identified 40 individuals, and surveys between May and October 2018 identified 5 individuals 
(Godefroy de Bruyne, pers. comm., 14/09/18). Observers on board national trawlers off Gabon have not recorded the species in monitoring which commenced in 2015, despite many species of rays being recorded (Emmanuel Chartrain, pers. comm., 15/02/19). In Port Gentil, Gabon (around 400 boats), where rays are targeted, $R$. luebberti has not been seen during ongoing surveys that commenced in June 2017 (Godefroy de Bruyne, pers. comm., 14/09/18). A 2006 capture by a recreational fishing guide in Guinea-Bissau was reportedly described as 'very, very rare' (Moore, 2017). It was also recently confirmed from Sao Tomé Island through a photographic record (Reiner \& Wirst, 2016).

\subsection{IUCN Red List categories}

All wedgefishes and giant guitarfishes were assessed as CR A2, with the exception of $R$. palpebratus which was assessed as NT (nearly meeting criterion A2). That is, 15 out of 16 species are inferred to have undergone a population reduction of $>80 \%$ over the last three generations ( $30-45$ years), where 'the causes of reduction may not have ceased OR may not be understood OR may not be reversible' (IUCN, 2012). In this case, the causes are understood (over-exploitation in target and bycatch fisheries, driven by human consumption and trade in meat and fins), they are theoretically reversible (through the implementation of management measures; see Discussion), but they have not ceased (largely unregulated exploitation continues with fishing effort increasing). These population reductions are based on 'an index of abundance appropriate to the taxon' (IUCN, 2012), i.e. the declines in landings and catch rates presented above, and 'actual or potential levels of exploitation' (IUCN, 2012), i.e. high levels of exploitation in target and bycatch fisheries. Red List categories and criteria along with a brief assessment justification for wedgefishes are provided in Table 4 and for giant guitarfishes in Table 5 .

Parts of Australasia and South Africa stand apart as the clear exceptions to the widespread intense fisheries elsewhere. Four species (R. ancylostoma, R. australiae, R. palpebratus, and G. typus) occur in tropical and warm-temperate waters of Australia where fishing pressure is relatively low and fisheries management measures are in place. For widely-distributed species $(R$. ancylostoma, $R$. australiae, and G. typus) this proportion of the species' range is not considered to be large enough relative to the global range to lower the global $C R$ assessment status. The bulk of the currently recognised distribution of $R$. palpebratus is within Australian waters, influencing its more favourable global status of NT, compared to the other species. It should be noted however, that the full distribution of this species is not well understood, and the disjunct records (Australia/New Guinea, Thai Andaman Sea, and Taiwan; Compagno \& Last, 2008; Ebert et al., 2013; Last et al., 2016c) suggests that it is/was more widely ranging throughout Southeast Asia and Australasia, or that there is an unresolved taxonomic 
population reduction over the last three generations ( 45 years) in the Asian part of its range. There is little contemporary information on the species outside of Australia, and it has not been recorded in recent landing site surveys on the Andaman coast of Thailand (Shin Arunrugstichai, pers. comm., $16 / 01 / 19)$. If the species was in fact wider-ranging throughout the Indo-Malay Archipelago/Southeast Asia, as its disjunct distribution suggests, it would likely have undergone a population reduction over the last three generations high enough to qualify it for a threatened category (possibly as high as CR, the status of all other wedgefishes).

Generally, there are few catch and trend data for elasmobranchs in the Eastern Atlantic and there was no population trend information available for the three species found there: $R$. luebberti, $R$. mauritaniensis, and G. cemiculus. Nevertheless, inference can be drawn from general regional fisheries trends. Fishing effort and the number of fishers has increased in recent decades across West Africa, with demand for shark and ray product increasing over the same period due to the shark fin trade (Diop \& Dossa, 2011). For example, large regional fishing nations including Mauritania and Senegal have seen significant increases in fishing effort since the second half of the 20th Century, with considerable artisanal and industrial fishing fleets operating in waters off West Africa (ANSD, 2016; Belhabib et al., 2012; FAO, 2008; ONS, 2017). The severe population reductions inferred for Indo-West Pacific wedgefishes and giant guitarfishes from several datasets could likely be considered representative of the situation in the Eastern Atlantic. Indeed, heavy exploitation has led to the depletion of $R$. luebberti and the possible disappearance of $R$. mauritaniensis.

\subsection{Possible extinction of two wedgefish species}

The most at-risk species are those with very-restricted ranges: $R$. cooki of the Indo-Malay Archipelago and $R$. mauritaniensis of Mauritania, both of which may be very close to extinction, even before they were taxonomically described in 2016 (Last et al., 2016a; Séret \& Naylor, 2016). The full distribution of $R$. cooki is unclear as it has only been collected from fish landing sites in Singapore and Jakarta (Indonesia), and these landings come from fisheries that operate widely across the Indo-Malay Archipelago (Last et al., 2016a). There has only been a single record of this species since 1996 (an individual observed at a Singapore fish market in early 2019; Naomi Clark-Shen and Kathy Xu, pers. comm., 26/05/2019). The limited number of records in a heavily fished and scientifically well-surveyed area raises serious concerns for the species. Further surveys are required to understand its contemporary occurrence and status, and ongoing monitoring of fish markets should pay special attention to wedgefish landings while making an effort to determine from fishers where the species was caught, and therefore its natural range. 
503

504

505

506

507

508

509

510

511

512

513

514

515

516

517

518

519

520

521

522

523

524

525

526

527

528

529

530

531

532

533

534

535

Rhynchorhina mauritaniensis is known only from one location, the Banc d'Arguin National Park, Mauritania. The Indigenous Imraguen population of the local area were traditionally subsistence fishers until a shift to commercial shark fishing from the mid-1980s (see Belhabib et al., 2012; Diop \& Dossa, 2011). This shift, along with increasing artisanal and industrial fishing effort in Mauritanian waters possibly depleted the population even before it was formally described by Séret \& Naylor (2016). This species is known to occur in an area where targeting of sharks has been prohibited since 2003 (Diop \& Dossa, 2011) and only Indigenous fishers are permitted to fish using traditional methods (the Banc d'Arguin National Park). However, the artisanal fishing effort in the National Park, combined with illegal fishing effort is considerable (Belhabib et al., 2012), and R. mauritaniensis is known to be landed locally. Individuals have been observed with their fins removed when landed, and the fins sold to local fin dealers (Séret \& Naylor, 2016). This species is not likely to have any refuge from fishing within its very restricted range given the combined effort from subsistence, artisanal, and illegal fishing coupled with the high value of its fins. The species' extent of occurrence is estimated to be $<5,000 \mathrm{~km}^{2}$, which combined with its presence in only one location, and an inferred continuing decline in the number of mature individuals due to this ongoing fishing pressure, meets EN under criterion $B$ (as EN B1ab(v)) (IUCN, 2012). However, a lack of records, high actual levels of exploitation, and a broad understanding of declines of similar species in the Indo-West Pacific, as well as the locally-occurring $R$. luebberti, also lead us to infer that $R$. mauritaniensis has undergone a $>80 \%$ population reduction over the last three generations ( 45 years) and is assessed as CR A2d.

The poorly-known R. immaculatus is also considered to be at elevated risk. It is another species known only from fishing landing sites, in this case, in northern Taiwan (Last et al., 2013). The lack of records suggests a very limited distribution which raises serious concerns for its ability to sustain historic and current levels of fishing pressure. Taiwan is a major fishing nation with a long history of exploitation of coastal resources, which were considered to be overfished by the 1950s (and which led to the development of Taiwan's distant water fleet) (Kuo \& Booth, 2011). Taiwan ranks among the top 20 shark fishing nations globally (Lack \& Sant, 2011) and is a major global shark fin trading nation (Clarke et al., 2006; Dulvy et al., 2014). Furthermore, there is an extensive illegal, unreported, and unregulated (IUU) fishing issue in Taiwan (Kuo \& Booth, 2011).

\subsection{Red List Index}

The global RLI for wedgefishes and giant guitarfishes starts relatively high in 1980 at 0.7 , declining steadily to 0.43 in 2005 and further to 0.24 in the current assessment (2020) (Figure 3a). The global index is driven mainly by the greater diversity of the Indo-West Pacific, which has a similar RLI in 1980 of 0.63. In the Eastern Atlantic however, a steep decline in RLI occurs between 1980 to 2005, from 1 
to 0.4 , compared to the Indo-West Pacific, which declines from 0.63 to 0.43 over the same time period

537 (Figure 3a). This difference in decline rates is likely due to the later development of wedgefish and

538 giant guitarfish fisheries and fin trade in the Eastern Atlantic. By 1980, it is inferred that 11 species were already likely to be threatened (i.e. Red List category of CR, EN, or VU); all these species occur in the Indo-West Pacific, where there has been an early development of fisheries and trade, particularly in Asia with its proximity to Hong Kong as the major shark fin trade centre. For example, $R$. immaculatus (Indo-West Pacific), is inferred as already CR by 1980 due to the early development of intensive fisheries in Taiwan and proximity to Hong Kong. By contrast, all three species found in the Eastern Atlantic were LC in 1980 (thus resulting in RLI of 1 for the region; Figure 3a). By 2005, it was inferred that at a global level, one species was CR, 13 were EN, one was VU, and one was NT. By the current assessment (2020), the RLI has declined to 0.25 and 0.2 for the Indo-West Pacific, and the Eastern Atlantic, respectively (Figure 3a).

The trends in wedgefish and giant guitarfish fisheries and fin trade described above are reflected in the geographic regions that display the sharpest declines in Red List Index between the different assessment years (Figure 3b and c). Declines in RLI between 1980 and 2005 are concentrated in West African and Mediterranean Sea nations (Figure 3b), shifting to East African nations between 2005 and 2020 (Figure 3c). Declines are less severe in the Indo-West Pacific since most species are already likely threatened by 1980 (Figure 3b and c). Species' ranges in the Eastern Atlantic and the Indo-West Pacific overlap with the EEZ of forty-one and forty-six nations, respectively (Figure 3d, Table 6). The top ten percent of nations in the Eastern Atlantic responsible for the conservation of species in this region are Mauritania, Guinea, Guinea-Bissau, and Nigeria (collectively representing 57\% of all national responsibility for the region); in the Indo-West Pacific, these nations are Indonesia, India, Australia, Taiwan, and Malaysia (representing 55\% of all responsibility for the region; Figure 3d, Table 6).

\section{DISCUSSION}

560 This study brings together several lines of evidence to show severe population reductions in wedgefishes and giant guitarfishes globally, resulting in 15 of 16 species (94\%) facing an 'extremely high risk of extinction', i.e. assessed as Critically Endangered on the IUCN Red List. That makes these the most imperilled marine fish families globally, overtaking the sawfishes which are comprised of three CR and 2 EN species (IUCN, 2019). The demand for shark and ray products, including the highvalue 'white' fins of wedgefishes and giant guitarfishes will continue to drive and incentivise targeting and retention, and urgent action is required to prevent extinctions. Next, the following topics are considered: (1) data quality and knowledge gap issues in assessing extinction risk in wedgefishes and giant guitarfishes; (2) the intersection between species richness and threat; (3) the current shortfall in 
conservation and management; (4) Australia as a refuge for a quarter of the fauna; and, (5) measures that are needed to prevent extinction.

\section{$571 \quad 4.1 \quad$ Data quality and knowledge gaps}

572 Most of the available data upon which these assessments were based were catch landings under 573 broad aggregate categories such as 'giant guitarfish', 'rhinobatid', and 'whitespotted wedgefishes'. 574 These non-species-specific groupings limit the possibility of analysing population trends for individual 575 species but are useful to infer trends based on overlapping habitat and depth ranges across species, 576 and likely similar catchability in extensive coastal and shelf fisheries in tropical and warm temperate 577 Indo-West Pacific and Eastern Atlantic waters.

578 Although landings data are not a direct measure of abundance, these can be used to infer population 579 reduction where landings have decreased while fishing effort has remained stable or increased, hence 580 approximating a decline in CPUE. In nearly all cases used here to assess population status, there was no reason to suspect that overall effort had decreased (although directed fishing effort may have shifted in response to resource collapse/depletion; e.g. the Aru Islands gillnet fishery in Indonesia). In fact, fishing effort and power is continuing to increase globally as the coastal human population continues to grow and fishing technology and market access improves. Some of the highest increases in fishing effort and power occur in the Asian region (Anticamara, Watson, Gelchu, \& Pauly, 2011; Watson et al., 2013), which is a centre of wedgefish and giant guitarfish diversity. Hence, declining catches are inferred to likely indicate reductions in abundance.

All of the wedgefishes and giant guitarfishes were assessed using the IUCN Red List 'Population size reduction' A criterion (IUCN, 2012; IUCN, 2019; Mace et al., 2008). The IUCN Red List Criteria were designed to allow a range of data quality to be used, allowing taxa to be assessed in the absence of complete, high-quality datasets (IUCN Standards and Petitions Subcommittee, 2017). Moving from the highest to the lowest levels of acceptable data quality, IUCN accepts information that is 'observed'

593 (e.g. population decline based on well-documented observations of all known individuals in the population); 'estimated' (e.g. population decline based on repeated surveys that involve statistical assumptions); 'projected' (e.g. a future population decline model based on past repeated surveys and threats that are unlikely to stop); 'inferred' (e.g. a population decline based on trade or fisheries landings data), or 'suspected' (e.g. information based on circumstantial evidence). For the wedgefishes and giant guitarfishes, population reductions were 'inferred'. Of the available contemporary datasets, only the catch rate data of myliobatoid rays from Maharashtra, India (Raje \& Zacharia 2009) could be used to 'estimate' a population reduction (86-95\% over three generations). 
601

602

603

604

605

606

607

608

609

610

611

612

613

614

615

616

617

618

619

620

621

622

623

624

625

626

627

628

629

630

631

632

However, when applied to the assessment of wedgefish and giant guitarfish extinction risk, the data quality was low since population reductions were inferred from another demersal ray lineage (Myliobatiformes). Because the datasets used from Iran, Pakistan, and Indonesia (DGCF, 2015; 2017; FAO, 2018a; M.A. Gore, unpubl. data) consisted of landings only, these could only be used to 'infer' population reduction.

Inferring population reductions from broad landings data of aggregate species categories highlighted the data deficiency around these species, not only in catch and trade data, but also in basic habitat and life history parameters. For example, amongst the wedgefishes, depth ranges are completely unknown for three species, annual fecundity is unknown across the family (and litter size is known from only four species), and generation length had to be inferred from giant guitarfishes. Across both families, age and growth studies are restricted to only two published works (Enajjar et al., 2012; White et al., 2014), with no accurate data for wedgefishes given that White et al. (2014) analysed mixed species samples.

\subsection{The intersection between species richness and threat}

Species richness is highest in areas of significant fishing effort, and these hotspots of overlap between diversity and pressure may be priorities for management. The Indo-West Pacific (13 species) is the centre of diversity for wedgefishes and giant guitarfishes, with low diversity in the Eastern Atlantic (three species), and no species in the Western Atlantic or Eastern Pacific. The Northern Indian Ocean, particularly the Arabian/Persian Gulf to India, and the Indo-Malay Archipelago are areas of special concern. These regions include several countries that rank among the top 20 shark fishing nations globally, specifically Indonesia, India, Pakistan, Malaysia, Thailand, Sri Lanka, and Iran (Lack \& Sant, 2011) and are under high levels of coastal fishing effort (Stewart et al., 2010). Unsurprisingly, there have been steep declines in shark and ray landings over the past decade in this region likely due to the collapse of chondrichthyan stocks (Davidson, Krawchuk, \& Dulvy, 2016) It is informative to consider the sheer number of fishing vessels in operation in these regions, for example (1) all Indian states have high numbers of fishing vessels (e.g. as reported in 2010: Maharashtra, 5,613 trawlers; Kerala, 3,678 trawlers, Tamil Nadu, 5,767 trawlers; total trawlers in India: 35,228 ) and a high number of gillnetters (total of 20,257 as reported in 2010), (2) Oman with 19,000 artisanal boats, (3) Pakistan with 2,000 trawlers, (4) Sri Lanka with 24,600 gillnet vessels operating in 2004; and, (5) Indonesia with 600,000 fishing vessels in marine waters (CMFRI, 2010; Dissanayake, 2005; Jabado et al., 2017; KKP, 2016). The intensity of fishing pressure on the coastal and shelf waters leaves little refuge for wedgefishes and giant guitarfishes. 
While fishing pressure is the primary threat driving population reduction of wedgefishes and giant guitarfishes, these effects are compounded by habitat loss and degradation. The shallow, inshore softbottom habitat preferred by the species is threatened by habitat loss and environmental degradation (Jabado et al., 2017; Moore, 2017; Moore, McCarthy, Carvalho, \& Peirce, 2012; Stobutzki et al., 2006; White \& Sommerville, 2010). In the Arabian Sea and adjacent waters, dredging and coastal land reclamation has increased in recent years and has resulted in almost total loss of mangroves in some areas, such as Bahrain (Jabado et al., 2017; Sheppard et al., 2010), while Southeast Asia has seen an estimated 30\% reduction in mangrove area since 1980 (FAO, 2007; Polidoro et al., 2010). Combined with targeted and bycatch fishing, the cumulative impacts of habitat loss and degradation will hinder recovery.

\subsection{Current shortfall in conservation and management}

There are minimal international and national management measures in place for wedgefishes and giant guitarfishes, and these are not at the scale currently required to curtail the severe extinction risk of these species. Regarding international agreements, $R$. australiae was listed on Appendix II of the Convention on the Conservation of Migratory Species of Wild Animals (CMS) in 2017 which aims to provide a framework for the coordination of measures adopted by Range States to improve the conservation of the species. However, listing is not the same as implementation; a recent review of implementation of CMS listings revealed serious deficiencies in implementation across Range States (Lawson \& Fordham, 2018). The CMS Memorandum of Understanding on the Conservation of Migratory Sharks also lists R. australiae, R. djiddensis, and R. laevis on Annex 1 (since December 2018). Annex 1 lists species that have an unfavourable conservation status and would significantly benefit from collaborative international conservation action. Glaucostegus cemiculus is listed on Annex II of the Specially Protected Areas and Biological Diversity Protocol for the Mediterranean under the Barcelona Convention, and cannot be retained on board, trans-shipped, landed, transferred, stored, sold, displayed or offered for sale, and must be released unharmed and alive (to the extent possible). European Union (EU) vessels are prohibited from fishing for guitarfishes in EU waters of several International Council for the Exploration of the Sea (ICES) sub-areas.

At the national or subnational level, there are very limited species-specific conservation or management measures in place. Some localised protections, trawl bans, finning bans, as well as general fisheries management and marine protected areas likely benefit these species, although in many areas, effective enforcement is an ongoing issue. Of 87 countries whose waters are home to one or more species of wedgefish or giant guitarfish, only eight have specific national or subnational level protections in place: (1) Guinea, where $R$. luebberti is protected (specified within the annual national 
666

667

668

669

670

671

672

673

674

675

676

677

678

679

680

681

682

683

684

685

686

687

688

689

690

691

692

693

694

695

696

697

698

fisheries management plan rather than the Fisheries Code); (2) South Africa, where $R$. djiddensis is protected; (3) Israel, where all sharks and rays are protected; (4) the United Arab Emirates (UAE), where all wedgefishes and guitarfishes are protected; (5) Kuwait, where all rays are protected; (6) Pakistan, where all guitarfishes and wedgefishes are protected in Balochistan province, and where juvenile guitarfishes and wedgefishes (less than $30 \mathrm{~cm}$ ) are protected in Sindh province (note that this size limit is below the known size-at-birth of all wedgefishes and most giant guitarfishes; Tables 1 \& 2); (7) India, where ' $R$. djiddensis' is protected; and, (8) Bangladesh, where ' $R$. djiddensis' and $G$. granulatus are protected. However, R. djiddensis does not occur in India or Bangladesh (Last et al., 2016c), and the species present there, $R$. australiae and $R$. laevis, are currently not listed on national legislation. Collectively, these countries represent only $19 \%$ of all conservation responsibility in the Indo-West Pacific and just 8\% in the Eastern Atlantic (Israel and Guinea only).

The UAE, Qatar, and Oman have banned trawling in their waters, Malaysia has banned trawling in inshore waters, and other countries have seasonal trawl closures that may benefit species. Finning (i.e. removing fins and discarding the body at sea) has been banned in several range states including some West African countries, UAE, Oman, Iran, Israel, and Australia. This may have reduced the retention of animals solely for their fins, but fins are still traded when whole animals are landed. Furthermore, unreported finning of sharks and 'guitar sharks' has been reported in the Mauritania industrial shrimp fishery (Goudswaard \& Meissa, 2006) and no doubt occurs more widely.

\subsection{Lifeboat Australia}

Across the global range of wedgefishes and giant guitarfishes, Australia offers some refuge for the four species occurring there ( $R$. ancylostoma, $R$. australiae, $R$. palpebratus, and G. typus), particularly as Australia has the third highest conservation responsibility for all species occurring in the Indo-West Pacific. Fishing pressure is considerably lower in the tropical and subtropical waters of the northern half of the Australian continent than most places in the Indo-West Pacific, although the degree of connectivity with Indonesia and elsewhere is unknown. If animals regularly move into Indonesian waters, they would face significantly higher levels of fishing pressure. There are no target fisheries for these species in Australia, although they are taken as bycatch in numerous non-target fisheries (e.g. Stobutzki, Miller, Heales, \& Brewer, 2002; White, Heupel, Simpfendorfer, \& Tobin, 2013). The introduction of turtle exclusion devices in northern and eastern Australian prawn trawl fisheries is likely to have significantly reduced the mortality of these species in trawl fishing gear (Brewer et al., 2006). Furthermore, in the state of Queensland there is a trip limit of five wedgefishes in commercial net fisheries (DAFF, 2009) and in all jurisdictions, there are prohibitions on retention of any shark product in several fisheries. General recreational shark and ray possession limits are also in place. 
Lastly, Australia has a system of marine protected areas stretching across the distribution of wedgefishes and G. typus, and although these are multi-use parks, they include areas with limitations on fishing activities. Collectively, this management seascape may offer these species a 'lifeboat', a term first used by Fordham et al. (2018) in the context of Australia and sawfishes.

\subsection{Preventing extinction}

The application of IUCN Red List Categories and Criteria to wedgefishes and giant guitarfishes has shown that without immediate action, there is an extremely high likelihood of global extinction for most species. Declines in Red List Indices are severe at global, regional, and national levels, with a relatively small number of countries responsible for the majority of conservation of these species. Accurate extinction risk assessments are essential to inform policy and decision making, and to improve conservation efforts and sustainable management of shark-like rays. It is therefore necessary to continue to refine future assessments by resolving taxonomic issues, improving our understanding of species distributions and life histories, and monitoring threats.

Taxonomic resolution combined with accurate species-specific identification would greatly enhance gathering life history and habitat data, and lead to improved fisheries monitoring data recording. However, accurate identification is wanting, particularly in the 'whitespotted wedgefish' speciescomplex. While R. ancylostoma and R. mauritaniensis are distinctive, the eight Rhynchobatus species are morphologically similar externally, and are usually separated, if at all, by the patterning of spots around a black pectoral marking. The problem with separating these species based on spot patterns is that these may change with growth and natural variations between animals. Further compounding the matter is the poor original descriptions for many of these species; two Rhynchobatus species ( $R$. djiddensis, R. laevis) were described over 215 years ago, and two others (R. luebberti, R. australiae) were described 114 and 80 years ago, respectively. In the past 11 years four new species (R. cooki, $R$. immaculatus, $R$. palpebratus, $R$. springeri) have been described, but most were based on smaller juvenile specimens, without consideration of ontogenetic changes in spot patterning. The giant guitarfishes are even more problematic since all were described more than 175 years ago, with their descriptions being poor. A taxonomic revision of both families is needed with corresponding field identification guides to improve specific-species data collection.

International trade in highly prized and valuable fins is a major driver of over-exploitation in wedgefishes and giant guitarfishes (Dent \& Clarke, 2015; Hau et al., 2018; Jabado, 2018; 2019; Moore, 2017; Suzuki, 2002) and hence, trade regulation is an important part of the solution to reduce incentives to serially deplete populations of these species. Two species of wedgefish (R. australiae and 

for listing under Appendix II of the Convention on the International Trade in Endangered Species, with all other members of both families to be listed under the 'look alike' criterion. An Appendix II listing enables international trade to be controlled through export permits issued by Parties where the specimen was legally obtained and if the export will not be detrimental to the survival of the species' (CITES, 2019). There are currently 183 Parties to CITES so this instrument has broad global reach (CITES, 2019), yet implementation and enforcement are ongoing issues.

A logical first step to guide and prioritise actions for these species is a global conservation planning exercise. A global sawfish strategy was instrumental in catalysing research and monitoring for sawfishes (Fordham et al., 2018; Harrison \& Dulvy, 2014), although much work remains to be done to secure those species. To conserve wedgefish and giant guitarfish populations and to permit recovery, a suite of national, regional, and international measures will be required which will need to include species protection, spatial management, bycatch mitigation, and harvest and international trade management measures. Effective enforcement of measures will require ongoing training and capacitybuilding (including improving species identification; Jabado, 2019). Catch monitoring, especially in artisanal fisheries, is needed to help understand local population trends and inform management. The dire situation of two wedgefish species, $R$. cooki and $R$. mauritaniensis, outlined here highlights the urgency of global concerted action.

This work was funded by the Shark Conservation Fund as part of the Global Shark Trends Project. We thank all members of the IUCN Species Survival Commission Shark Specialist Group and other experts who contributed to the data collation to inform Red List assessments. In particular, we extend our gratitude to Sall Amadou, Shin Arunrugstichai, Emmanuel Chartrain, Naomi Clark-Shen, Godefroy de Bruyne, Katie Gledhill, Adrian Gutteridge, Saïkou Oumar Kidé, Peter Last, Muhammad Moazzam Khan, Alec Moore, Nomfundo Nakabi, Bernard Séret, Umer Waqas, and Kathy Xu. PMK was supported by the Marine Biodiversity Hub, a collaborative partnership supported through funding from the Australian Government's National Environmental Science Program. MAG was supported by a Darwin Initiative grant. DAE was supported by the South African Institute for Aquatic Biodiversity and the Save Fund. 
Agence Nationale de la Statistique et de la Demographie (ANSD). (2016). Situation economique et sociale du Senegal en 2013. Republique du Senegal: Ministere de I'Economie, des Finances et du Plan.

Anticamara, J. A., Watson, R., Gelchu, A., \& Pauly, D. (2011). Global fishing effort (1950-2010): trends, gaps, and implications. Fisheries Research, 107, 131-136.

Barrowclift, E., Temple, A. J., Stead, S., Jiddawi, N. S., \& Berggren, P. (2017). Social, economic and trade characteristics of the elasmobranch fishery on Unguja Island, Zanzibar, East Africa. Marine Policy, $83,128-136$.

Belhabib, D., Gascuel, D., Kane, E. A., Harper, S., Zeller, D., \& Pauly, D. (2012). Preliminary estimation of realistic fisheries removals from Mauritania, 1950-2010. In Belhabib, D., Zeller, D., Harper, S., \& Pauly, D. (Eds.), Marine fisheries catches in West Africa, 1950-2010, part I. Fisheries Centre Research Reports 20(3) (pp. 61-78), Vancouver, Canada: Fisheries Centre, University of British Columbia.

Blaber, S., Dichmont, C. M., White, W. T., Buckworth, R. C., Sadiyah, L., Iskandar, B., ... Fahmi. (2009). Elasmobranchs in southern Indonesian fisheries: the fisheries, the status of the stocks and management options. Reviews in Fish Biology and Fisheries, 19, 367-391.

Bonfil, R. \& Abdallah, M. (2004). Field identification guide to the sharks and rays of the Red Sea and Gulf of Aden. FAO species identification guide for fishery purposes. Rome, Italy: Food and Agriculture Organization of the United Nations (FAO).

Bradaï, M. N., Saidi, B., Enajjar, S., \& Bouain, A. (2006). The Gulf of Gabès: a spot for the Mediterranean elasmobranches. In Basusta, N., Keskin, Ç., Serena, F., \& Séret, B. (Eds.), The proceedings of the workshop on Mediterranean cartilaginous fish with emphasis on southern and eastern Mediterranean (pp. 107-117), Istanbul, Turkey: Turkish Marine Research Foundation.

Brewer, D., Heales, D., Milton, D., Dell, Q., Fry, G., Venables, B., \& Jones, P. (2006). The impact of turtle excluder devices and bycatch reduction devices on diverse tropical marine communities in Australia's northern prawn trawl fishery. Fisheries Research, 81, 176-188.

Bruckner, A. W., Alnazry, H. H., \& Faisal, M. (2011). A paradigm shift for fisheries management to enhance recovery, resilience, and sustainability of coral reef ecosystems in the Red Sea. In Taylor, W. W., Lynch, A. J., \& Schechter, M. G. (Eds.), Sustainable fisheries: multi-level approaches to a global problem (pp. 85-111), Herndon, VA: American Fisheries Society.

Capapé, C. \& Zaouali, J. (1994). Distribution and reproductive biology of the Blackchin Guitarfish, Rhinobatos cemiculus (Pisces: Rhinobatidae), in Tunisian waters (central Mediterranean). Australian Journal of Marine and Freshwater Research, 45, 551-561.

Central Marine Fisheries Research Institute (CMFRI). (2010). Marine fisheries census (2010), part 1. New Delhi, India: Government of India, Ministry of Agriculture, Department of Animal Husbandry, Dairying and Fisheries, and Central Marine Fisheries Research Institute, Indian Council of Agricultural Research.

Chen, H. K. (Ed.) (1996). Shark fisheries and the trade in sharks and shark products in Southeast Asia. TRAFFIC Southeast Asia Report. Petaling Jaya, Selangor, Malaysia: TRAFFIC. 
Clarke, S. C., McAllister, M. K., Milner-Gulland, E. J., Kirkwood, G. P., Michielsens, C. G. J., Agnew, D. J., ... \& Shivji, M. S. (2006). Global estimates of shark catches using trade records from commercial markets. Ecology Letters, 9, 1115-1126.

Clarke, S., Milner-Gulland, E. J., \& Bjorndal, T. (2007). Social, economic, and regulatory drivers of the shark fin trade. Marine Resource Economics, 22, 305-327.

Compagno, L. J. V. \& Last, P. R. (2008). A new species of wedgefish, Rhynchobatus palpebratus sp. nov. (Rhynchobatoidei: Rhynchobatidae), from the Indo-West Pacific. In Last, P. R., White, W. T., \& Pogonoski, J. J. (Eds.), Descriptions of new Australian chondrichthyans. CSIRO Marine and Atmospheric Research Paper 022 (pp. 227-240), Hobart, Australia: CSIRO Marine and Atmospheric Research.

Compagno, L. J. V. \& Last, P. R. (2010). A new species of wedgefish, Rhynchobatus springeri (Rhynchobatoidei, Rhynchobatidae), from the Western Pacific. In Last, P. R., White, W. T., \& Pogonoski, J. J. (Eds.), Descriptions of new sharks and rays from Borneo. CSIRO Marine and Atmospheric Research Paper 032 (pp. 77-88), Hobart, Australia: CSIRO Marine and Atmospheric Research.

Convention on International Trade in Endangered Species of Wild Fauna and Flora (CITES). (2019). http://www.cites.org/ [20 March 2019].

Cripps, G., Harris, A., Humber, F., Harding, S., \& Thomas, T. (2015). A preliminary value chain analysis of shark fisheries in Madagascar. IOTC-2015-WPEB11-17. SF/2015/34. Mauritius: Indian Ocean Tuna Commission Working Party on Ecosystems and Bycatch.

Davidson, L. N. K., Krawchuk, M. A., \& Dulvy, N. K. (2016). Why have global shark and ray landings declined: improved management or overfishing? Fish and Fisheries, 17, 438-458.

De Buen, F. (1935). Fauna ictiológica. Catálogo de los peces ibéricos: de la planicie continental, aguas dulces, pelágicos y de los abismos próximos. Parte: Notas y Resúmenes Instituto Español de Oceanografía. Ser. II, 89, 91-149.

Dent, F. \& Clarke, S. (2015). State of the global market for shark products. FAO Fisheries and Aquaculture Technical Paper No. 590. Rome, Italy: Food and Agriculture Organization of the United Nations (FAO).

Department of Agriculture, Fisheries and Forestry (DAFF). (2009). Guidelines for commercial operators in the Inshore Fin Fish Fishery. Brisbane, Australia: Department of Agriculture, Fisheries and Forestry.

Diop, M. \& Dossa, J. (2011). 30 years of shark fishing in West Africa: Development of fisheries, catch trends, and their conservation status in Sub-Regional Fishing Commission member countries. Fondation Internationale du Banc d'Arguin (FIBA), Regional Partnership for Coastal and Marine Conservation (PRCM), and Commission Sous Régionale des Pêches, Sub-Regional Fisheries Commission (CSRP, SRFC).

Directorate General of Capture Fisheries (DGCF). (2015). Capture fisheries statistics of Indonesia. Jakarta, Indonesia: Directorate General of Capture Fisheries. 
Directorate General of Capture Fisheries (DGCF). (2017). Capture fisheries statistics of Indonesia by province. Vol. 17 No.1. Jakarta, Indonesia: Ministry of Marine Affairs and Fisheries.

Dirzo, R., Young, H. S., Galetti, M., Ceballos, G., Isaac, N. J. B., \& Collen, B. (2014). Defaunation in the Anthropocene. Science, 345, 401-406.

Dissanayake, D. C. T. (2005). Monitoring and assessment of the offshore fishery in Sri Lanka. Reykjavik, Iceland: The United Nations University Fisheries Training Programme.

Doderlein, P. (1884). Ricorrenza del Rhinobatus halavi Rupp. nelle acque marine della Sicilia. Naturalista Siciliano, 3, 169-175.

Dulvy, N. K., Sadovy, Y., \& Reynolds, J. D. (2003). Extinction vulnerability in marine populations. Fish and Fisheries, 4, 25-64.

Dulvy, N. K., Pinnegar, J. K., \& Reynolds, J. D. (2009). Holocene extinctions in the sea. In Turvey, S. T. (Ed.), Holocene extinctions (pp. 129-150), Oxford, UK: Oxford University Press.

Dulvy, N. K., Davidson, L. N. K., Kyne, P. M., Simpfendorfer, C. A., Harrison, L. R., Carlson, J. K., \& Fordham, S. V. (2016). Ghosts of the coast: global extinction risk and conservation of sawfishes. Aquatic Conservation: Marine and Freshwater Ecosystems, 26, 134-153.

Dulvy, N. K., Fowler, S. L., Musick, J. A., Cavanagh, R. D., Kyne, P. M., Harrison, L. R., ... White, W. T. (2014). Extinction risk and conservation of the world's sharks and rays. elife, 3, e00590.

Ebert, D. A., White, W. T., Ho, H.-C., Last, P. R., Nakaya, K., Séret, B., ... de Carvalho, M. R. (2013). An annotated checklist of the chondrichthyans of Taiwan. Zootaxa, 3752, 279-386.

Echwikhi, K., Saidi, B., \& Bradaï, M. N. (2014). Elasmobranchs longline fisheries in the Gulf of Gabès (southern Tunisia). Journal of the Marine Biological Association of the United Kingdom, 94, 203210.

Enajjar, S., Bradai, M. N., \& Bouain, A. (2012). Age, growth and sexual maturity of the blackchin guitarfish Rhinobatos cemiculus in the Gulf of Gabès (southern Tunisia, central Mediterranean). Cahiers de Biologie Marine, 53, 17-23.

ESRI. (2016). ArcGIS Desktop: Release 10.6.1. Redlands, CA: Environmental Systems Research Institute.

Faria, V. V., McDavitt, M. T., Charvet, P., Wiley, T. R., Simpfendorfer, C. A., \& Naylor, G. J. P. (2013). Species delineation and global population structure of Critically Endangered sawfishes (Pristidae). Zoological Journal of the Linnean Society, 167, 136-164.

Ferretti, F., Osio, G. C., Jenkins, C. J., Rosenberg, A. A., \& Lotze, H. K. (2013). Long-term change in a meso-predator community in response to prolonged and heterogeneous human impact. Scientific Reports, 3, 1057.

Food and Agriculture Organization of the United Nations (FAO). (2007). The world's mangroves 19802005. FAO Forestry Paper 153. Rome, Italy: Forestry Department, Food and Agriculture Organization of the United Nations (FAO). 
Food and Agriculture Organization of the United Nations (FAO). (2008). Vue générale du secteur des pêches national la République du Sénégal. Fishery and aquaculture country profiles. Rome, Italy: Food and Agriculture Organization of the United Nations (FAO).

Food and Agriculture Organization of the United Nations (FAO). (2018a). FAO fishstat capture production database 1950-2015. http://www.fao.org/fishery/statistics/software/fishstatj/en [01 December 2018].

Food and Agriculture Organization of the United Nations (FAO). (2018b). Summary of the status of demersal stocks in the northern area of the Eastern Central Atlantic (CECAF). Fishery Committee for the Eastern Central Atlantic Scientific Sub-Committee. Eighth Session, Abidjan, Côte d'Ivoire, 23-26 October 2018. CECAF/SSCVIII/2018/4.

Fordham, S. V., Jabado, R., Kyne, P. M., Charvet, P., \& Dulvy, N. K. (2018). Saving sawfish: Progress and priorities. Vancouver, Canada: IUCN Shark Specialist Group.

Goudswaard, P. C. \& Meissa, B. O. (2006). Discards in the Mauritanian shrimp fisheries. An evaluation of lost value. Wageningen Institute for Marine Resources and Ecosystem Studies. Report Number: c067/06.

Gohar, H. A. F. \& Mazhar, F. M. (1964). The elasmobranchs of the north-western Red Sea. Publications of the Marine Biological Station Al-Ghardaqa (Red Sea), 13, 1-144.

Haque, A. B., Biswas, A. R., \& Latifa, G. A. (2018). Observations of shark and ray products in the processing centres of Bangladesh, trade in CITES species and conservation needs. TRAFFIC Bulletin, 30, 6-14.

Harrison, L. R. \& Dulvy, N. K. (Eds.). (2014). Sawfish: A global strategy for conservation. Vancouver, Canada: IUCN Species Survival Commission's Shark Specialist Group.

Hau, C. Y., Abercrombie, D. L., Ho, K. Y. K., \& Shea, K. H. S. (2018). "King of shark fins" not quite sharks...so what is in my soup. A rapid survey on the availability of shark-like batoid fins in Hong Kong SAR and Guangzhou, China retail markets. Hong Kong: BLOOM Hong Kong Shark Foundation.

Humber, F., Andriamahaino, E. T., Beriziny, T., Botosoamananto, R., Godley, B. J., Gough, C., ... Broderick, A. C. (2017). Assessing the small-scale shark fishery of Madagascar through communitybased monitoring and knowledge. Fisheries Research, 186, 131-143.

Indian Ocean Tuna Commission (IOTC). (2005). Information on shark finning fisheries. IOTC-2005-S908[EN]. Victoria, Seychelles: IOTC.

IUCN. (2012). IUCN Red List Categories and Criteria: Version 3.1. Second edition. Gland, Switzerland and Cambridge, UK: IUCN.

IUCN. (2019). The IUCN Red List of Threatened Species. Version 2019-2. http://www.iucnredlist.org

IUCN Standards and Petitions Subcommittee. (2017). Guidelines for using the IUCN Red List Categories and Criteria. Version 13. Prepared by the Standards and Petitions Subcommittee. Gland, Switzerland and Cambridge, UK: IUCN. 
Jabado, R. W. (2018). The fate of the most threatened order of elasmobranchs: Shark-like batoids (Rhinopristiformes) in the Arabian Sea and adjacent waters. Fisheries Research, 204, 448-457.

Jabado, R. W. (2019). Wedgefishes and giant guitarfishes: A guide to species identification. New York, NY: Wildlife Conservation Society.

Jabado, R. W., Kyne, P. M., Pollom, R. A., Ebert, D. A., Simpfendorfer, C. A., Ralph, G. M., \& Dulvy, N. K. (eds.). (2017). The conservation status of sharks, rays, and chimaeras in the Arabian Sea and adjacent waters. UAE: Environment Agency - Abu Dhabi; and Vancouver, Canada: IUCN Species Survival Commission Shark Specialist Group.

Kementerian Kelautan dan Perikanan (KKP). (2016). KPDA. Pusat Data dan Statistik. Jakarta, Indonesia: Kementerian Kelautan dan Perikanan.

Kuo, D. \& Booth, S. (2011). From local to global: A catch reconstruction of Taiwan's fisheries from 1950-2007. In Harper, S. \& Zeller, D. (Eds.), Fisheries catch reconstructions: Islands, part II. Fisheries Centre Research Reports 19(4) (pp. 97-106), Vancouver, Canada: University of British Columbia.

Lack, M. \& Sant, G. (2011). The future of sharks: A review of action and inaction. TRAFFIC International and the Pew Environment Group.

Last, P. R. \& Stevens, J. D. (2009). Sharks and rays of Australia. Second edition. Collingwood: CSIRO Publishing.

Last, P. R., Ho, H.-C., \& Chen, R.-R. (2013). A new species of wedgefish, Rhynchobatus immaculatus (Chondrichthyes, Rhynchobatidae), from Taiwan. Zootaxa, 3752, 185-198.

Last, P. R., Kyne, P. M., \& Compagno, L. J. V. (2016a). A new species of wedgefish Rhynchobatus cooki (Rhinopristiformes, Rhinidae) from the Indo-West Pacific. Zootaxa, 4139, 233-247.

Last, P. R., Séret, B., \& Naylor, G. J. P. (2016b). A new species of guitarfish, Rhinobatos borneensis sp. nov. with a redefinition of the family-level classification in the order Rhinopristiformes (Chondrichthyes: Batoidea). Zootaxa, 4117, 451-475.

Last, P., White, W., de Carvalho, M., Séret, B., Stehmann, M., \& Naylor, G. (2016c). Rays of the world. Clayton: CSIRO Publishing.

Lawson, J. M. \& Fordham, S. V. (2018). Sharks ahead: Realizing the potential of the Convention on Migratory Species to conserve elasmobranchs. CMS/Sharks/MOS3/Inf.21. Washington, DC: Shark Advocates International, The Ocean Foundation.

Lteif, M. (2015). Biology, distribution and diversity of cartilaginous fish species along the Lebanese coast, eastern Mediterranean (PhD thesis). Université de Perpignan, France.

Mace, G. M., Collar, N. J., Gaston, K. J., Hilton-Taylor, C., Akçakaya, H. R., Leader-Williams, N., ... Stuart, S. N. (2008). Quantification of extinction risk: IUCN's system for classifying threatened species. Conservation Biology, 22, 1424-1442.

McCauley, D. J., Pinsky, M. L., Palumbi, S. R., Estes, J. A., Joyce, F. H., \& Warner, R. R. (2015). Marine defaunation: Animal loss in the global ocean. Science, $347,1255641$. 
Mohamed, K. S. \& Veena, S. (2016). How long does it take for tropical marine fish stocks to recover after declines? Case studies from the southwest coast of India. Current Science, 110, 584-594.

Mohanraj, G., Rajapackiam, S., Mohan, S., Batcha, H., \& Gomathy, S. (2009). Status of elasmobranchs fishery in Chennai, India. Asian Fisheries Science, 22, 607-615.

Moore, A. B. M. (2017). Guitarfishes: The next sawfishes? Extinction vulnerabilities and an urgent call for conservation action. Endangered Species Research, 34, 75-88.

Moore, A. B. M. \& Peirce, R. (2013). Composition of elasmobranch landings in Bahrain. African Journal of Marine Science, 35, 593-596.

Moore, A. B. M., McCarthy, I. D., Carvalho, G. R., \& Peirce, R. (2012). Species, sex, size and male maturity composition of previously unreported elasmobranch landings in Kuwait, Qatar and Abu Dhabi Emirate. Journal of Fish Biology, 80, 1619-1642.

Moore, A. B. M., Séret, B., \& Armstrong, R. (2019). Risks to biodiversity and coastal livelihoods from artisanal elasmobranch fisheries in a Least Developed Country: The Gambia (West Africa). Biodiversity and Conservation doi.org/10.1007/s10531-019-01732-9

Newell, B. N. (2016). Draft status review report of two species of guitarfish: Rhinobatos rhinobatos and Rhinobatos cemiculus. Draft report to National Marine Fisheries Service, Office of Protected Resources.

Office National de la Statistique (ONS). (2017). Annuaire statistique 2016. Republique Islamique de Mauritanie: Office National de la Statistique, Ministere de l'Economie et des Finances.

Pauly, D. (1979). Theory and management of tropical multispecies stocks: A review, with emphasis on the Southeast Asian demersal fisheries. ICLARM Studies and Reviews No. 1. Manila, Philippines: International Center for Living Aquatic Resources Management.

Pauly, D. \& Chuenpagdee, R. (2003). Development of fisheries in the Gulf of Thailand Large Marine Ecosystem: Analysis of an unplanned experiment. In Hempeland, G. and Sherman, K. (Eds.), Large marine ecosystems of the world 12: Change and sustainability (pp. 337-354), Amsterdam, Netherlands: Elsevier Science.

Pierce S., Trerup M., Williams C., Tilley A., Marshall A., \& Raba N. (2008). Shark fishing in Mozambique: A preliminary assessment of artisanal fisheries. Maputo, Mozambique: Eyes on the Horizon.

Polidoro, B. A., Carpenter, K. E., Collins, L., Duke, N. C., Ellison, A. M., Ellison, J. C., ... Hong Yong, J. W. (2010). The loss of species: mangrove extinction risk and geographic areas of global concern. PLoS ONE, 5, e10095.

Quignard, J. P. \& Capapé, C. (1971). Liste commentée des sélaciens de Tunisie. Salammbô Bulletin de I'Institut National scientifique et Technique d'Océanographie et de Pêche, 2(2), 13-41.

Raje, S. G. \& Zacharia, P. U. (2009). Investigations on fishery and biology of nine species of rays in Mumbai waters. Indian Journal of Fisheries, 56, 95-101. 
Reiner, F. \& Wirtz, P. (2016). Five new records of coastal fishes from São Tomé Island. Revista de la Academia Canaria de Ciencias, XXVIII, 127-131.

Relini, G. \& Piccinetti, C. (1991). Stato attuale dei censimenti ittici nei mari Italiani. Atti II Seminario Italiano Censimenti Faunistici dei Vertebrati. Supplemento alle Ricerche di Biologia della Selvaggina, XVI, 29-54.

Ritragsa, S. (1976). Results of the studies on the status of demersal fish resources in the Gulf of Thailand from trawling surveys, 1963-1972. In Tiews, K. (Ed.), Fisheries resources and their management in Southeast Asia (pp. 198-223), Berlin (West), Germany: German Foundation for International Development, Federal Research Board for Fisheries, and Food and Agriculture Organization of the United Nations (FAO).

Seck, A. A., Diatta, Y., Diop, M., Guélorget, O., Reynaud, C., \& Capapé, C. (2004). Observations on the reproductive biology of the blackchin guitarfish, Rhinobatos cemiculus E. Geoffroy Saint-Hillaire, 1817 (Chondrichthyes, Rhinoabatidae) from the coast of Senegal (Eastern Tropical Atlantic). Scientia Gerundensis, 27, 19-30.

Seisay, M. (2005). Shark fishery study: Sierra Leone. Freetown, Sierra Leone: Sub-Regional Shark Programme, Sub-Regional Fisheries Commission, Fisheries Department.

Séret, B. \& Naylor, G. J. P. (2016). Rhynchorhina mauritaniensis, a new genus and species of wedgefish from the eastern central Atlantic (Elasmobranchii: Batoidea: Rhinidae). Zootaxa, 4138, 291-308.

Sheppard, C., Al-Husiani, M., Al-Jamali, F., Al-Yamani, F., Baldwin, R., Bishop, J., ... Dutrieux, E. (2010). The Gulf: A young sea in decline. Marine Pollution Bulletin, 60, 13-38.

Soldo, A., Briand, F., \& Rassoulzadegan, K. (2014). CIESM forum - In search of rare shark species. The Mediterranean Science Commission. http://www.ciesm.org/forums/index.php?post/Sharks [20 March 2014].

Sousa, M. I., Marshall, N. T., \& Smale, M. J. (1997). The shark trade in Mozambique. In: Marshall, N. T. \& Barnett, R. (Eds.), The trade in sharks and shark products in the western Indian and southeast Atlantic oceans (pp. 67-79), Nairobi, Kenya: TRAFFIC East/Southern Africa.

Stewart, K. R., Lewison, R. L., Dunn, D. C., Bjorkland, R. H., Kelez, S., Halpin, P. N., \& Crowder, L. B. (2010). Characterizing fishing effort and spatial extent of coastal fisheries. PLOS ONE, 5, e14451.

Stobutzki, I. C., Miller, M. J., Heales, D. S., \& Brewer, D. T. (2002). Sustainability of elasmobranches caught as bycatch in a tropical prawn (shrimp) trawl fishery. Fishery Bulletin, 100, 800-821.

Stobutzki, I. C., Silvestre, G. T., Abu Talib, A., Krongprom, A., Supongpan, M., Khemakorn, P., ... Garces, L. R. (2006). Decline of demersal coastal fisheries resources in three developing Asian countries. Fisheries Research, 78, 130-142.

Suzuki, T. (2002). Development of shark fisheries and shark fin export in Indonesia: case study of Karangsong Village, Indramayu, West Java. In Fowler, S. L., Reed, T. M., \& Dipper, F. A. (Eds.), Elasmobranch biodiversity, conservation and management: Proceedings of the international seminar and workshop, Sabah, Malaysia, July 1997 (pp. 149-157), Gland, Switzerland and Cambridge, UK: IUCN SSC Shark Specialist Group. 
Tirtadanu, Suprapto, \& Suwarso. (2018). Composition, distribution, stock density and biomass of rays in Java sea. Prosiding Simposium Nasional Hiu Pari Indonesia Ke-2 Tahun 2018. Jakarta, Indonesia: KKP-Misol-Cl-WWF.

Tous, P., Ducrocq, M., Bucal, D., \& Feron, E. (1998). Shark populations are possibly under serious threat in the Bijagos archipelago (Biosphere Reserve), Guinea Bissau, West Africa, Shark News. Newsletter of the IUCN Shark Specialist Group, 10, 4.

van der Elst, R. (1993). A Guide to the common sea fishes of Southern Africa. Cape Town, South Africa: Struik Publishers.

Watson, R. A., Cheung, W. W. L., Anticamara, J. A., Sumaila, R. U., Zeller, D., \& Pauly, D. (2013). Global marine yield halved as fishing intensity redoubles. Fish and Fisheries, 14, 493-503.

White, J., Heupel, M. R., Simpfendorfer, C. A., \& Tobin, A. J. (2013). Shark-like batoids in Pacific fisheries: prevalence and conservation concerns. Endangered Species Research, 19, 277-284.

White, J., Simpfendorfer, C. A., Tobin, A. J., \& Heupel, M. R. (2014). Age and growth parameters of shark-like batoids. Journal of Fish Biology, 84, 1340-1353.

White, W. T. \& Dharmadi (2007). Species and size compositions and reproductive biology of rays (Chondrichthyes, Batoidea) caught in target and non-target fisheries in eastern Indonesia. Journal of Fish Biology, 70, 1809-1837.

White, W. T., \& Sommerville, E. (2010). Elasmobranchs of tropical marine ecosystems. In Carrier, J. C., Musick, J. A., \& Heithaus, M. R. (Eds.), Sharks and their relatives II. Biodiversity, adaptive physiology, and conservation (pp. 159-239), Boca Raton, FL: CRC Press.

Whitehead, P. J. P., Bauchot, M. L., Hureau, J. C., Nielsen, J., \& Tortonese, E. (Eds.). (1984). Fishes of the North-eastern Atlantic and the Mediterranean Vol 1. Paris, France: UNESCO.

Yusup, H. N, Priatna, A., \& Wagiyo, K. (2018). Distribution and abundance of fish in the area of fishery management (fma) 711: North Natuna Sea waters. Prosiding Simposium Nasional Hiu Pari Indonesia Ke-2 Tahun 2018. Jakarta, Indonesia: KKP-Misol-CI-WWF.

Zhou, S. J. \& Griffiths, S. P. (2008). Sustainability Assessment for Fishing Effects (SAFE): A new quantitative ecological risk assessment method and its application to elasmobranch bycatch in an Australian trawl fishery. Fisheries Research, 91, 56-68.

Zynudheen, A. A., Ninan, G., Sen, A., \& Badonia, R. (2004). Utilization of trawl bycatch in Gujarat (India). NAGA Worldfish Center Quarterly, 27(3\&4), 20-23. 
TABLE 1 Distribution and life history of wedgefishes (Rhinidae). Life history data from Last \& Stevens (2009); Last et al. (2016c); van der Elst (1993); White \& Dharmadi (2007).

\begin{tabular}{|c|c|c|c|c|c|c|c|}
\hline Species & Distribution & $\begin{array}{l}\text { Depth range } \\
(\mathrm{m})\end{array}$ & $\begin{array}{l}\text { Maximum size } \\
\quad(\mathrm{cm} \mathrm{TL})\end{array}$ & $\begin{array}{l}\text { Size-at-maturity } \\
\text { (cm TL) }\end{array}$ & $\begin{array}{l}\text { Size-at-birth } \\
\text { (cm TL) }\end{array}$ & Litter Size & $\begin{array}{c}\text { Generation } \\
\text { Length (years) }\end{array}$ \\
\hline $\begin{array}{l}\text { Bowmouth Guitarfish } \\
\text { Rhina ancylostoma Bloch \& Schneider, } 1801\end{array}$ & $\begin{array}{l}\text { Indo-West } \\
\text { Pacific }\end{array}$ & Inshore-70 & 270 & 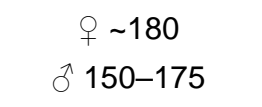 & $46-48$ & $2-11$ & 15 \\
\hline $\begin{array}{l}\text { Bottlenose Wedgefish } \\
\text { Rhynchobatus australiae Whitley, } 1939\end{array}$ & $\begin{array}{l}\text { Indo-West } \\
\text { Pacific }\end{array}$ & Inshore-60 & $\sim 300$ & $\begin{array}{l}\text { ㅇ } \sim 155 \\
\stackrel{1}{1} 110-130\end{array}$ & $46-50$ & $\begin{array}{c}\text { 7-19 } \\
\text { (mean 14) }\end{array}$ & 15 \\
\hline $\begin{array}{l}\text { Clown Wedgefish } \\
\text { Rhynchobatus cooki Last, Kyne \& Compagno, } 2016\end{array}$ & $\begin{array}{l}\text { Southeast } \\
\text { Asia }\end{array}$ & $\mathrm{n} / \mathrm{a}$ & 81 & $\begin{array}{l}+\mathrm{n} / \mathrm{a} \\
\hat{\delta}<70\end{array}$ & $\mathrm{n} / \mathrm{a}$ & $\mathrm{n} / \mathrm{a}$ & 10 \\
\hline $\begin{array}{l}\text { Whitespotted Wedgefish } \\
\text { Rhynchobatus djiddensis (Forsskål, 1775) }\end{array}$ & $\begin{array}{l}\text { Western } \\
\text { Indian }\end{array}$ & Inshore-70 & 310 & $\begin{array}{l}\text { o } \mathrm{n} / \mathrm{a} \\
\delta \sim 150\end{array}$ & 60 & 4 & 15 \\
\hline $\begin{array}{l}\text { Taiwanese Wedgefish } \\
\text { Rhynchobatus immaculatus Last, Ho \& Chen, } 2013\end{array}$ & Taiwan & $\mathrm{n} / \mathrm{a}$ & $>99 \dagger$ & $\begin{array}{l}+\mathrm{n} / \mathrm{a} \\
\hat{\partial} \mathrm{n} / \mathrm{a}\end{array}$ & $\mathrm{n} / \mathrm{a}$ & $\mathrm{n} / \mathrm{a}$ & 10 \\
\hline $\begin{array}{l}\text { Smoothnose Wedgefish } \\
\text { Rhynchobatus laevis (Bloch \& Schneider, 1801) }\end{array}$ & $\begin{array}{l}\text { Indo-West } \\
\text { Pacific }\end{array}$ & Inshore-60 & $>200$ & $\begin{array}{l}\text { o } \mathrm{n} / \mathrm{a} \\
\delta \sim 130\end{array}$ & $n / a$ & $\mathrm{n} / \mathrm{a}$ & 15 \\
\hline $\begin{array}{l}\text { African Wedgefish } \\
\text { Rhynchobatus luebberti Ehrenbaum, } 1915\end{array}$ & $\begin{array}{l}\text { Eastern } \\
\text { Atlantic }\end{array}$ & Inshore-35 & 300 & $\begin{array}{l}+\mathrm{n} / \mathrm{a} \\
\hat{o} \mathrm{n} / \mathrm{a}\end{array}$ & 79-85 & $2-5$ & 15 \\
\hline $\begin{array}{l}\text { Eyebrow Wedgefish } \\
\text { Rhynchobatus palpebratus Compagno \& Last, } 2008\end{array}$ & $\begin{array}{l}\text { Indo-West } \\
\text { Pacific }\end{array}$ & $5-61$ & 262 & $\begin{array}{l}q \mathrm{n} / \mathrm{a} \\
\hat{o} 103\end{array}$ & $46-50$ & $\mathrm{n} / \mathrm{a}$ & 15 \\
\hline $\begin{array}{l}\text { Broadnose Wedgefish } \\
\text { Rhynchobatus springeri Compagno \& Last, } 2010\end{array}$ & $\begin{array}{l}\text { Southeast } \\
\text { Asia }\end{array}$ & $16-40$ & 213 & 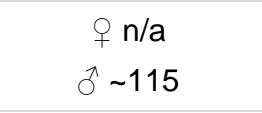 & $\mathrm{n} / \mathrm{a}$ & $\mathrm{n} / \mathrm{a}$ & 15 \\
\hline $\begin{array}{l}\text { False Shark Ray } \\
\text { Rhynchorhina mauritaniensis Séret \& Naylor, } 2016\end{array}$ & Mauritania & $\mathrm{n} / \mathrm{a}$ & 275 & $\begin{array}{l}+\mathrm{n} / \mathrm{a} \\
\hat{\mathrm{n}} \mathrm{n} / \mathrm{a}\end{array}$ & $\mathrm{n} / \mathrm{a}$ & $\mathrm{n} / \mathrm{a}$ & 15 \\
\hline
\end{tabular}

TL, total length; n/a, not available; †Immature male, maximum size suspected to be $\sim 150 \mathrm{~cm}$ TL. 
TABLE 2 Distribution and life history of giant guitarfishes (Glaucostegidae). Life history data from Capapé \& Zaouali (1994); Enajjar et al. (2012); Gohar \& Mazhar (1964); Last et al. (2016c); Moore et al. (2012); Moore \& Peirce (2013); Muhammad Moazzam Khan, pers. comm., 07/02/2019; Prasad (1951); Seck et al. (2004).

\begin{tabular}{|c|c|c|c|c|c|c|c|}
\hline Species & Distribution & $\begin{array}{l}\text { Depth range } \\
(\mathrm{m})\end{array}$ & $\begin{array}{l}\text { Maximum Size } \\
\quad(\mathrm{cm} \mathrm{TL})\end{array}$ & $\begin{array}{c}\text { Size-at-maturity (cm } \\
\text { TL) }\end{array}$ & $\begin{array}{l}\text { Size-at-birth } \\
\text { (cm TL) }\end{array}$ & $\begin{array}{l}\text { Litter } \\
\text { Size }\end{array}$ & $\begin{array}{c}\text { Generation } \\
\text { Length (yrs) }\end{array}$ \\
\hline $\begin{array}{l}\text { Blackchin Guitarfish } \\
\text { Glaucostegus cemiculus (Geoffroy St Hilaire, 1817) }\end{array}$ & $\begin{array}{c}\text { Eastern } \\
\text { Atlantic \& } \\
\text { Mediterranean } \\
\text { Sea }\end{array}$ & Inshore-80 & 265 & $\begin{array}{l}\text { o } 163 \text { (Senegal) } \\
\text { 110-138 (Tunisia) } \\
\text { o } 155 \text { (Senegal) } \\
\text { 100-112 (Tunisia) }\end{array}$ & $\sim 34$ & $\begin{array}{c}\text { 16-24 } \\
\text { (Senegal) } \\
5-12 \\
\text { (Tunisia) }\end{array}$ & 15 \\
\hline $\begin{array}{l}\text { Sharpnose Guitarfish } \\
\text { Glaucostegus granulatus (Cuvier, 1829) }\end{array}$ & $\begin{array}{l}\text { Northern } \\
\text { Indian }\end{array}$ & Inshore-120 & 229 & $\begin{array}{l}+\mathrm{n} / \mathrm{a} \\
o \mathrm{n} / \mathrm{a}\end{array}$ & $\sim 39$ & $6-18$ & 15 \\
\hline $\begin{array}{l}\text { Halavi Guitarfish } \\
\text { Glaucostegus halavi (Forsskål, 1775) }\end{array}$ & $\begin{array}{l}\text { Northern } \\
\text { Indian }\end{array}$ & Inshore-100 & 187 & $\begin{array}{l}\text { † } \sim 83 \\
\hat{0} \sim 83\end{array}$ & $\sim 29$ & up to 10 & 10 \\
\hline $\begin{array}{l}\text { Widenose Guitarfish } \\
\text { Glaucostegus obtusus (Müller \& Henle, 1841) }\end{array}$ & $\begin{array}{l}\text { Indo-West } \\
\text { Pacific }\end{array}$ & Inshore-60 & 93 & $\begin{array}{l}\uparrow \mathrm{n} / \mathrm{a} \\
\hat{o} \sim 48\end{array}$ & $\mathrm{n} / \mathrm{a}$ & $4-10$ & 10 \\
\hline $\begin{array}{l}\text { Clubnose Guitarfish } \\
\text { Glaucostegus thouin (Anonymous, 1798) }\end{array}$ & $\begin{array}{l}\text { Indo-West } \\
\text { Pacific }\end{array}$ & Inshore-60 & $\sim 300$ & $\begin{array}{l}+\mathrm{n} / \mathrm{a} \\
\hat{o} \mathrm{n} / \mathrm{a}\end{array}$ & $\mathrm{n} / \mathrm{a}$ & $\mathrm{n} / \mathrm{a}$ & 15 \\
\hline $\begin{array}{l}\text { Giant Guitarfish } \\
\text { Glaucostegus typus (Bennett, 1830) }\end{array}$ & $\begin{array}{l}\text { Indo-West } \\
\text { Pacific }\end{array}$ & Inshore-100 & 270 & $\begin{array}{l}\text { o } 150-180 \\
\text { ô } 150-180\end{array}$ & $38-40$ & $\mathrm{n} / \mathrm{a}$ & 15 \\
\hline
\end{tabular}

TL, total length; $n / a$, not available 
TABLE 3 Overall decline, annual proportional change, proportion remaining, and proportional decline over three generation lengths for landings and catch rate datasets. Proportional decline is provided for small $(<200 \mathrm{~cm} \mathrm{TL})$ and large $(\geq 200 \mathrm{~cm} \mathrm{TL})$ wedgefish and giant guitarfish species by applying a 3 generation length of 30 and 45 years, respectively.

\begin{tabular}{|c|c|c|c|c|c|c|c|c|c|c|}
\hline Location & \multicolumn{2}{|c|}{ Iran } & \multicolumn{2}{|c|}{$\begin{array}{l}\text { Sindh, } \\
\text { Pakistan }\end{array}$} & \multicolumn{2}{|c|}{$\begin{array}{c}\text { Balochistan, } \\
\text { Pakistan }\end{array}$} & \multicolumn{2}{|c|}{$\begin{array}{c}\text { Maharashtra, } \\
\text { India }\end{array}$} & \multicolumn{2}{|c|}{ Indonesia } \\
\hline Data type & \multicolumn{2}{|c|}{ Landings (t) } & \multicolumn{2}{|c|}{ Landings (t) } & \multicolumn{2}{|c|}{ Landings (t) } & \multicolumn{2}{|c|}{ Catch rate $(\mathrm{kg} / \mathrm{hr})$} & \multicolumn{2}{|c|}{ Landings $(\mathrm{t})$} \\
\hline Data category & \multicolumn{2}{|c|}{ 'giant guitarfish' } & \multicolumn{2}{|c|}{ 'rhinobatid' } & \multicolumn{2}{|c|}{ 'rhinobatid' } & \multicolumn{2}{|c|}{ 'myliobatoid rays' } & \multicolumn{2}{|c|}{ 'whitespotted wedgefishes' } \\
\hline Data period ( $x$ years) & \multicolumn{2}{|c|}{ 1997-2016 } & \multicolumn{2}{|c|}{ 1999-2011 } & \multicolumn{2}{|c|}{ 1994-2011 } & \multicolumn{2}{|c|}{ 1990-2004 } & \multicolumn{2}{|c|}{ 2005-2015 } \\
\hline Data source & \multicolumn{2}{|c|}{ FAO (2018a) } & \multicolumn{2}{|c|}{$\begin{array}{c}\text { M.A. Gore, unpubl. } \\
\text { data }\end{array}$} & \multicolumn{2}{|c|}{$\begin{array}{c}\text { M.A. Gore, unpubl. } \\
\text { data }\end{array}$} & \multicolumn{2}{|c|}{ Raje \& Zacharia (2009) } & \multicolumn{2}{|c|}{ DGCF $(2015 ; 2017)$} \\
\hline Proportional decline over $x$ years & \multicolumn{2}{|c|}{0.665} & \multicolumn{2}{|c|}{0.720} & \multicolumn{2}{|c|}{0.806} & \multicolumn{2}{|c|}{0.631} & \multicolumn{2}{|c|}{0.876} \\
\hline Annual proportional change & \multicolumn{2}{|c|}{0.947} & \multicolumn{2}{|c|}{0.907} & \multicolumn{2}{|c|}{0.913} & \multicolumn{2}{|c|}{0.936} & \multicolumn{2}{|c|}{0.827} \\
\hline 3 generation lengths (3GL) & $30 \mathrm{yrs}$ & 45 yrs & 30 yrs & 45 yrs & 30 yrs & 45 yrs & $30 \mathrm{yrs}$ & $45 \mathrm{yrs}$ & $30 \mathrm{yrs}$ & $45 \mathrm{yrs}$ \\
\hline Proportion remaining & 0.194 & 0.086 & 0.053 & 0.012 & 0.065 & 0.016 & 0.136 & 0.050 & 0.003 & 0.0002 \\
\hline Proportional decline over 3GL & 0.806 & 0.914 & 0.947 & 0.988 & 0.935 & 0.984 & 0.864 & 0.950 & 0.997 & 0.9998 \\
\hline
\end{tabular}


bioRxiv preprint doi: https://doi.org/10.1101/595462; this version posted June 10, 2019. The copyright holder for this preprint (which was not certified by peer review) is the author/funder, who has granted bioRxiv a license to display the preprint in perpetuity. It is made available under aCC-BY-NC-ND 4.0 International license.

TABLE 4 Summary of IUCN Red List (RL) Categories and Criteria for wedgefishes (Rhinidae).

\begin{tabular}{|c|c|c|}
\hline Species & $\begin{array}{l}\text { RL Category } \\
\text { \& Criteria }\end{array}$ & Justification \\
\hline Rhina ancylostoma & CR A2bd & $\begin{array}{l}\text { Indo-West Pacific population reductions in rhinopristoids; high levels } \\
\text { of exploitation across most of range; some refuge in Australia but not } \\
\text { considered a large enough proportion of range to lower assessment }\end{array}$ \\
\hline Rhynchobatus australiae & CR A2bd & $\begin{array}{l}\text { Indo-West Pacific population reductions in rhinopristoids; high levels } \\
\text { of exploitation across most of range; some refuge in Australia but not } \\
\text { considered a large enough proportion of range to lower assessment }\end{array}$ \\
\hline Rhynchobatus cooki & CR A2bd & $\begin{array}{l}\text { Indo-West Pacific population reductions in rhinopristoids; high levels } \\
\text { of exploitation across range; only a single record since } 1996 \text { in well } \\
\text { surveyed and heavily fished areas }\end{array}$ \\
\hline Rhynchobatus djiddensis & CR A2bd & $\begin{array}{l}\text { Indo-West Pacific population reductions in rhinopristoids; high levels } \\
\text { of exploitation across most of range; some refuge in South Africa but } \\
\text { not considered a large enough proportion of range to lower } \\
\text { assessment }\end{array}$ \\
\hline Rhynchobatus immaculatus & CR A2bd & $\begin{array}{l}\text { Indo-West Pacific population reductions in rhinopristoids; limited } \\
\text { distribution in heavily fished area; no refuge }\end{array}$ \\
\hline Rhynchobatus laevis & CR A2bd & $\begin{array}{l}\text { Indo-West Pacific population reductions in rhinopristoids; high levels } \\
\text { of exploitation across most of range; no refuge }\end{array}$ \\
\hline Rhynchobatus luebberti & CR A2d & $\begin{array}{l}\text { Once common and now only sporadically recorded; localised } \\
\text { extinction; high levels of exploitation across range; no refuge }\end{array}$ \\
\hline Rhynchobatus palpebratus & NT A2bd & $\begin{array}{l}\text { Assuming disjunct range of Australia/PNG, Thailand \& Taiwan (as } \\
\text { opposed to wider Australasian/Southeast Asian range): high levels of } \\
\text { exploitation in Thailand \& Taiwan, refuge in northern Australia } \\
\text { (significant proportion of range) }\end{array}$ \\
\hline Rhynchobatus springeri & CR A2bd & $\begin{array}{l}\text { Indo-West Pacific population reductions in rhinopristoids; high levels } \\
\text { of exploitation across range; no refuge }\end{array}$ \\
\hline Rhynchorhina mauritaniensis & CR A2d & $\begin{array}{l}\text { High levels of exploitation across range; absence of records; no } \\
\text { refuge }\end{array}$ \\
\hline
\end{tabular}

CR, Critically Endangered; NT, Near Threatened. 
bioRxiv preprint doi: https://doi.org/10.1101/595462; this version posted June 10, 2019. The copyright holder for this preprint (which was not certified by peer review) is the author/funder, who has granted bioRxiv a license to display the preprint in perpetuity. It is made available under aCC-BY-NC-ND 4.0 International license.

TABLE 5 Summary of IUCN Red List (RL) Categories and Criteria for giant guitarfishes (Glaucostegidae).

\begin{tabular}{|c|c|c|}
\hline Species & $\begin{array}{l}\text { RL Category } \\
\text { \& Criteria }\end{array}$ & Justification \\
\hline Glaucostegus cemiculus & CR A2d & $\begin{array}{l}\text { Localised extinctions in northern Mediterranean; high levels of } \\
\text { exploitation across West Africa; no refuge }\end{array}$ \\
\hline Glaucostegus granulatus & CR A2bd & $\begin{array}{l}\text { Indo-West Pacific population reductions in rhinopristoids; high levels } \\
\text { of exploitation across most of range; no refuge }\end{array}$ \\
\hline Glaucostegus halavi & CR A2bd & $\begin{array}{l}\text { Indo-West Pacific population reductions in rhinopristoids; high levels } \\
\text { of exploitation across most of range }\end{array}$ \\
\hline Glaucostegus obtusus & CR A2bd & $\begin{array}{l}\text { Indo-West Pacific population reductions in rhinopristoids; high levels } \\
\text { of exploitation across range; no refuge }\end{array}$ \\
\hline Glaucostegus thouin & CR A2bd & $\begin{array}{l}\text { Indo-West Pacific population reductions in rhinopristoids; high levels } \\
\text { of exploitation across range; rarity; no refuge }\end{array}$ \\
\hline Glaucostegus typus & CR A2bd & $\begin{array}{l}\text { Indo-West Pacific population reductions in rhinopristoids; high levels } \\
\text { of exploitation across most of range; some refuge in Australia but not } \\
\text { considered a large enough proportion of range to lower assessment }\end{array}$ \\
\hline
\end{tabular}

CR, Critically Endangered. 
TABLE 6 National conservation responsibilities (NCR) for all wedgefish and giant guitarfish species across 87 countries. Conservation responsibility (calculated as the sum of threat scores for each species weighted by the proportion of species range contained within each country's EEZ; see methods) is determined separately and normalised to range from 0 to 1 for comparability between the two distinct regions, the Eastern Atlantic Ocean and Mediterranean Sea region, and Indo-West Pacific Ocean region.

\begin{tabular}{|c|c|c|c|}
\hline \multicolumn{2}{|c|}{ Eastern Atlantic and Mediterranean Sea } & \multicolumn{2}{|c|}{ Indo-West Pacific } \\
\hline Country & NCR & Country & NCR \\
\hline Mauritania & 1 & Indonesia & 1 \\
\hline Guinea & 0.209 & India & 0.487 \\
\hline Guinea-Bissau & 0.172 & Australia & 0.322 \\
\hline Nigeria & 0.149 & Taiwan, Province of China & 0.242 \\
\hline Gabon & 0.112 & Malaysia & 0.221 \\
\hline Sierra Leone & 0.108 & Thailand & 0.202 \\
\hline Egypt & 0.101 & Myanmar & 0.177 \\
\hline Senegal & 0.086 & Islamic Republic of Iran & 0.166 \\
\hline Italy & 0.067 & China & 0.155 \\
\hline Tunisia & 0.066 & Saudi Arabia & 0.136 \\
\hline Ghana & 0.063 & United Arab Emirates & 0.122 \\
\hline Western Sahara & 0.062 & Eritrea & 0.086 \\
\hline Cameroon & 0.050 & Pakistan & 0.082 \\
\hline Angola & 0.048 & Vietnam & 0.080 \\
\hline Libya & 0.044 & Oman & 0.073 \\
\hline Greece & 0.041 & Bangladesh & 0.069 \\
\hline Liberia & 0.040 & Qatar & 0.068 \\
\hline Morocco & 0.036 & Philippines & 0.064 \\
\hline Croatia & 0.031 & Yemen & 0.056 \\
\hline Côte d'Ivoire & 0.030 & Mozambique & 0.048 \\
\hline Equatorial Guinea & 0.028 & Egypt & 0.040 \\
\hline Spain & 0.027 & Sri Lanka & 0.037 \\
\hline Gambia & 0.023 & Papua New Guinea & 0.030 \\
\hline Turkey & 0.019 & Somalia & 0.022 \\
\hline Congo & 0.016 & Cambodia & 0.022 \\
\hline Portugal & 0.015 & Kuwait & 0.020 \\
\hline Benin & 0.009 & Sudan & 0.018 \\
\hline France & 0.008 & Japan & 0.016 \\
\hline Algeria & 0.007 & Bahrain & 0.015 \\
\hline The Democratic Republic of the Congo & 0.007 & United Republic of Tanzania & 0.011 \\
\hline Togo & 0.005 & South Africa & 0.009 \\
\hline Israel & 0.004 & Kenya & 0.007 \\
\hline Albania & 0.004 & Republic of Korea & 0.007 \\
\hline
\end{tabular}


bioRxiv preprint doi: https://doi.org/10.1101/595462; this version posted June 10, 2019. The copyright holder for this preprint (which was not certified by peer review) is the author/funder, who has granted bioRxiv a license to display the preprint in perpetuity. It is made available under aCC-BY-NC-ND 4.0 International license.

\begin{tabular}{|l|c|l|c|}
\hline Cyprus & 0.002 & Madagascar & 0.006 \\
\hline Montenegro & 0.002 & Seychelles & 0.004 \\
\hline Lebanon & 0.001 & Brunei Darussalam & 0.003 \\
\hline Syrian Arab Republic & 0.001 & Maldives & 0.002 \\
\hline Malta & 0.001 & Singapore & 0.002 \\
\hline Slovenia & $<0.001$ & Israel & 0.002 \\
\hline Bosnia and Herzegovina & $<0.001$ & Democratic People's Republic of Korea & 0.002 \\
\hline Monaco & 0 & Djibouti & 0.001 \\
\hline & & Solomon Islands & 0.001 \\
\hline & & Iraq & 0.001 \\
\hline & & Timor-Leste & $<0.001$ \\
\hline & & Mauritius & $<0.001$ \\
\hline
\end{tabular}



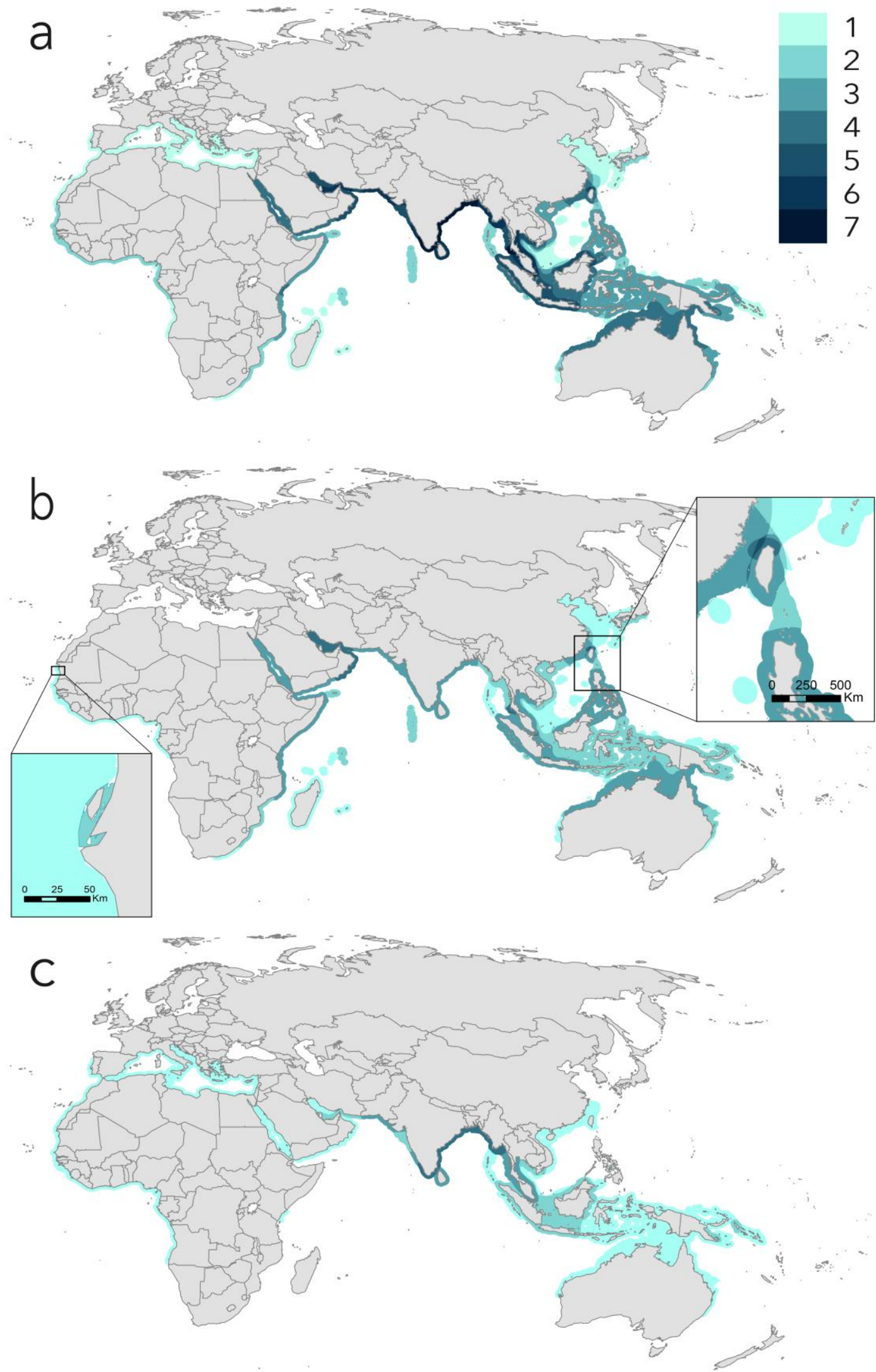

FIGURE 1 Wedgefish and giant guitarfish species richness: (a) Global species richness of wedgefishes and giant guitarfishes combined ( $n=16$ species); (b) Global species richness of wedgefishes $(n=10$ species); (c) Global species richness of giant guitarfishes ( $n=6$ species). 


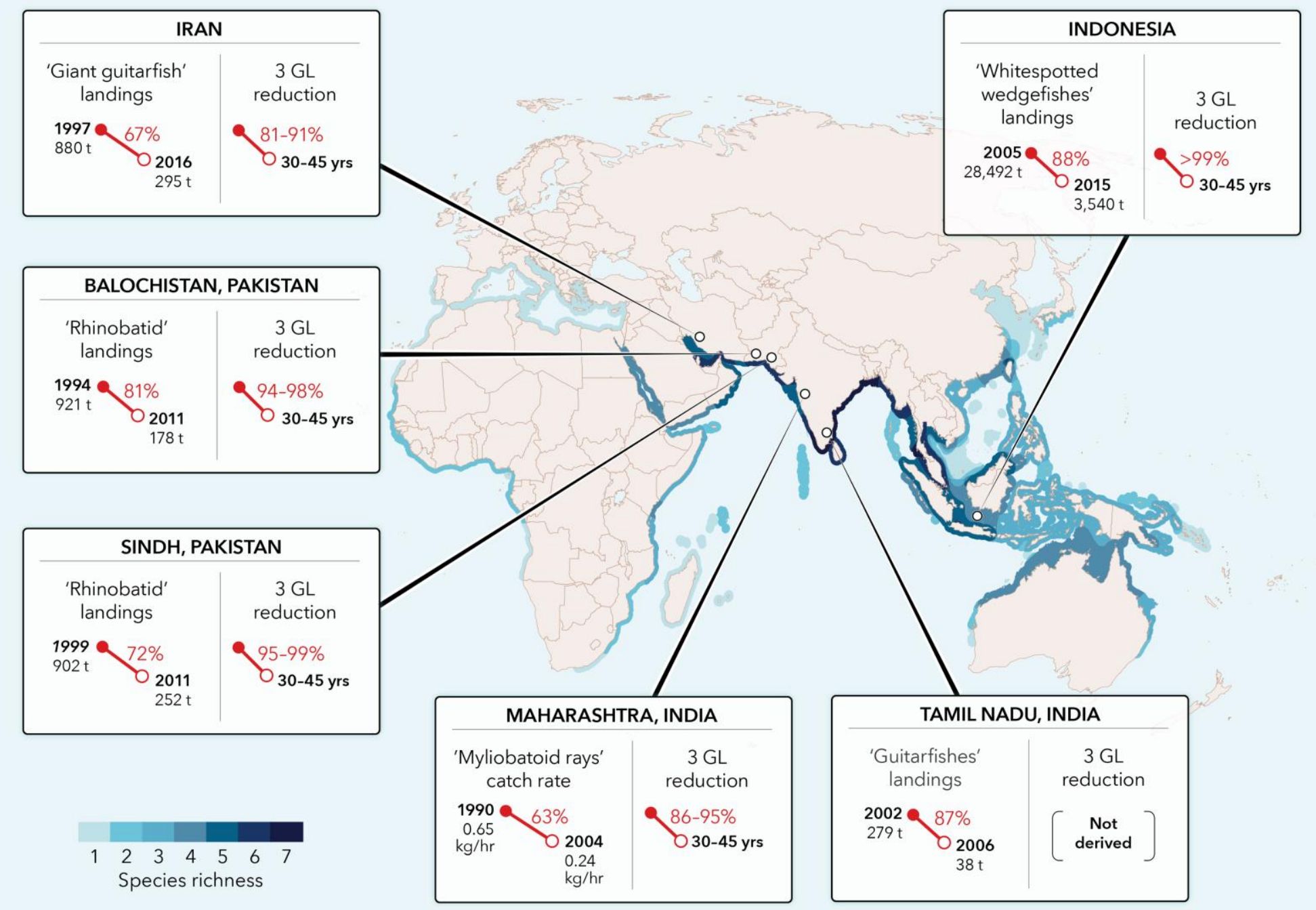

FIGURE 2 Summary of landings and catch rate data used to infer population reductions in wedgefishes and giant guitarfishes overlaid on the map of global species richness of wedgefishes and giant guitarfishes combined (Figure 1A). Data sources are provided in Table 3. GL, generation length. 

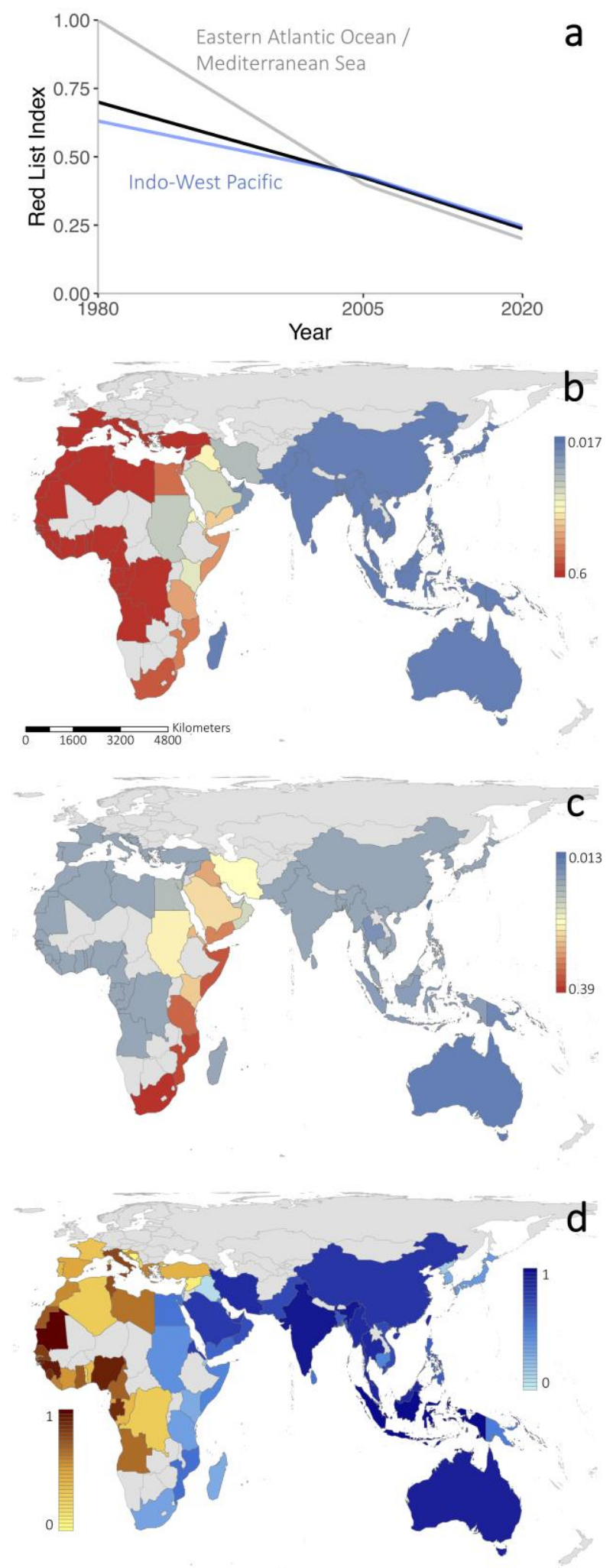

FIGURE 3 Red List Indices for wedgefishes and giant guitarfishes. (a) Global Red List Index (RLI; black line) decomposed for the two main oceanic regions, Indo-West Pacific Ocean (blue line), and the Eastern Atlantic Ocean and Mediterranean Sea (gray line); decline in country-weighted RLI from (b) 1980 to 2005, and (c) 2005 to 2020; and, (d) National conservation responsibilities for all wedgefish and giant guitarfish species across the two main regions, Indo-West Pacific Ocean (blues) and the Eastern Atlantic Ocean and Mediterranean Sea (yellows). 
bioRxiv preprint doi: https:/doi.org/10 1101/595462; this version posted June 10, 2019. The copyright holder for this preprint (which was not certified by peer review) is the author/funder, who has granted bioRxiv a license to display the preprint in perpetuity. It is made available under aCC-BY-NC-ND 4.0 International license.

APPENDIX I Individual species range maps for wedgefishes (a-j) and giant guitarfishes ( $\mathrm{k}-\mathrm{p})$ : (a) Rhina ancylostoma; (b) Rhynchobatus australiae; (c) Rhynchobatus cooki; (d) Rhynchobatus djiddensis; (e) Rhynchobatus immaculatus; (f) Rhynchobatus laevis; (g) Rhynchobatus luebberti; (h) Rhynchobatus palpebratus; (i) Rhynchobatus springeri; (j) Rhynchorhina mauritaniensis; (k) Glaucostegus cemiculus; (I) Glaucostegus granulatus; (m) Glaucostegus halavi; (n) Glaucostegus obtusus; (o) Glaucostegus thouin; (p) Glaucostegus typus.

a

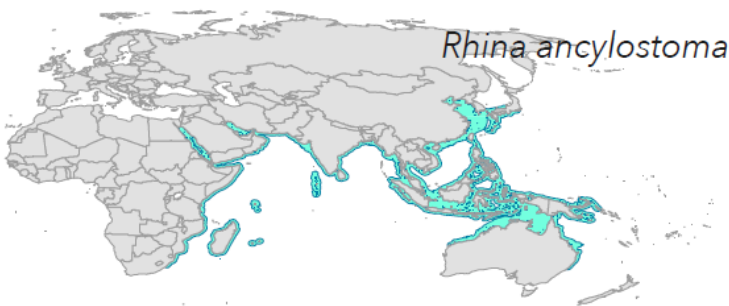

b

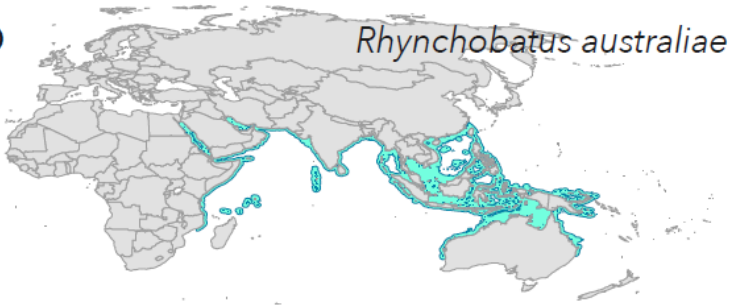

C

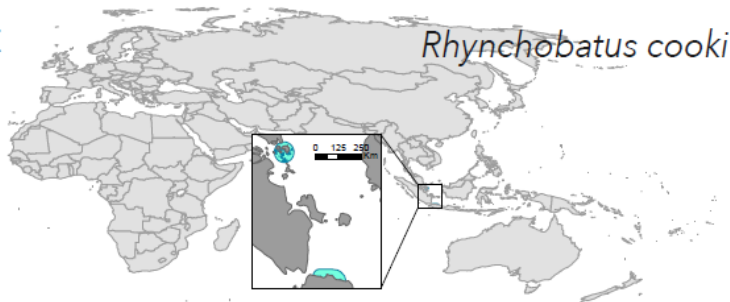

d

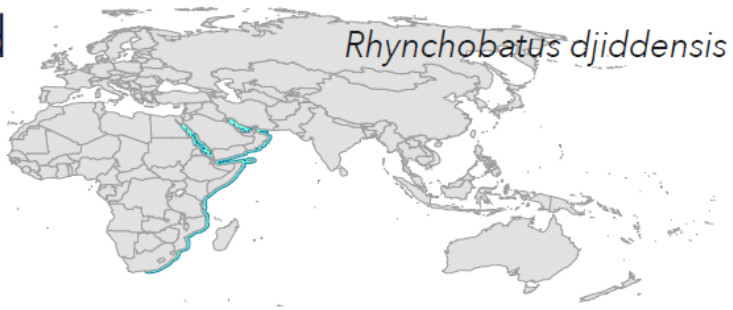

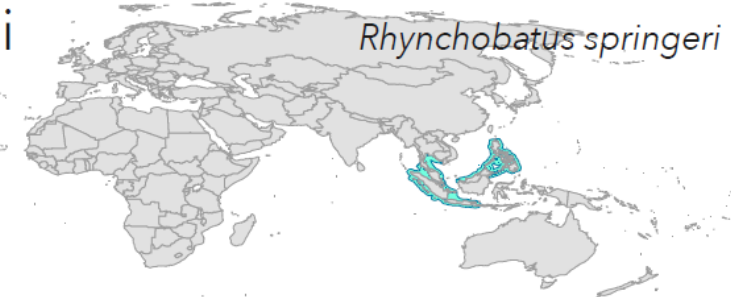

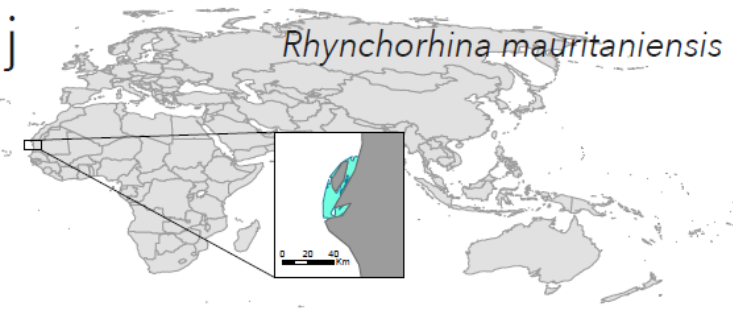

k

Glaucostegus cemiculus
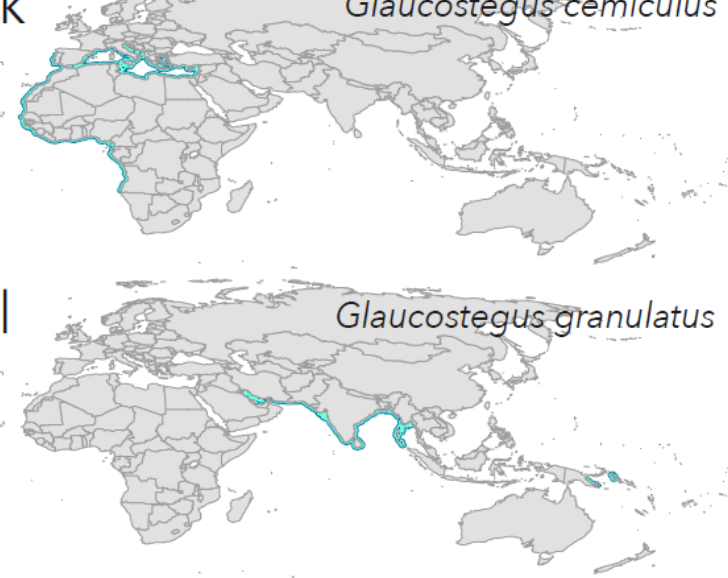
bioRxiv preprint doi: https://doi.org/10.1101/595462; this version posted June 10,2019 . The copyright holder for this preprint (which was

not certified by peer review) is the author/funder, who has granted bioRxiv a license to display the preprint in perpetuity. It is made available under aCC-BY-NC-ND 4.0 International license.

e

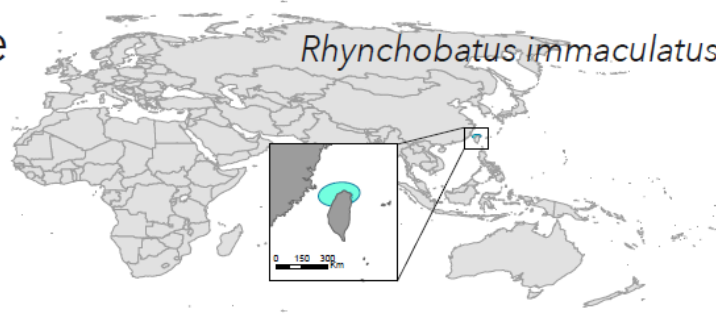

f

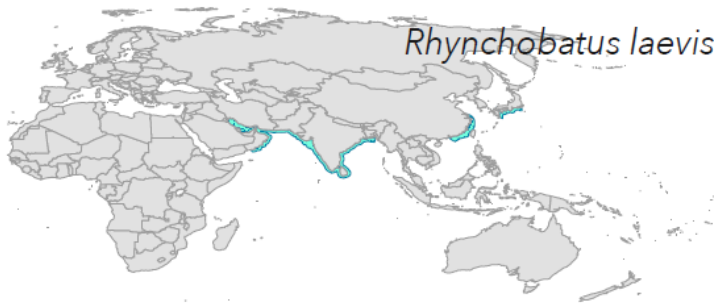

9

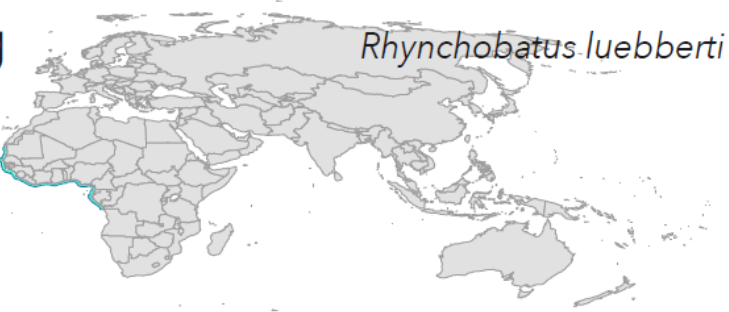

h Rhynchobatuspalpebratus

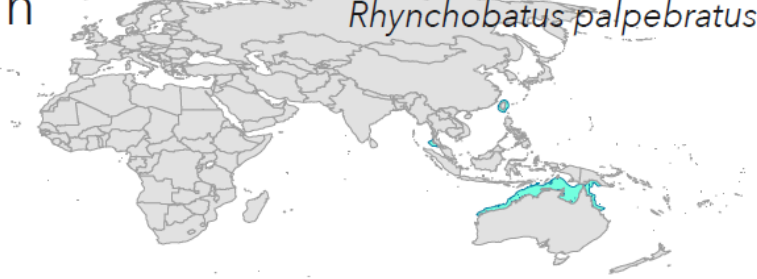

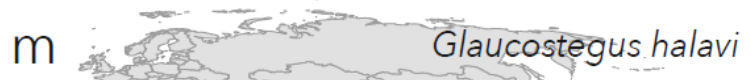
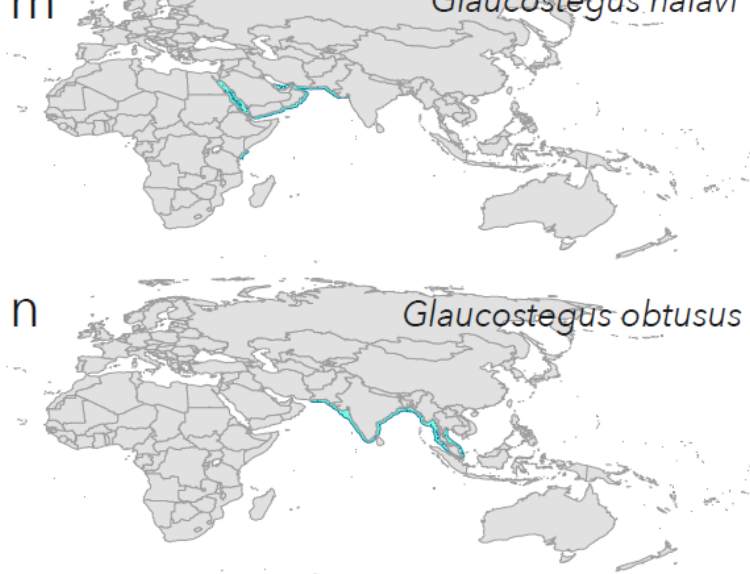

O Glaucostegus thouin

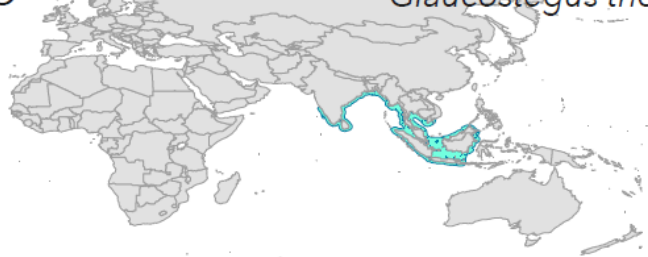

$P$ Glaucostegus typus

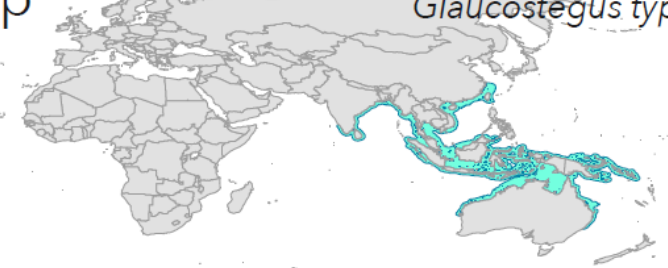

